\title{
The Polyglutamine Expansion in Spinocerebellar Ataxia Type 6 Causes a $\beta$ Subunit-Specific Enhanced Activation of P/Q-Type Calcium Channels in Xenopus Oocytes
}

\author{
Sophie Restituito, ${ }^{1}$ Randall M. Thompson, ${ }^{2}$ Jacob Eliet, ${ }^{1}$ Robert S. Raike, ${ }^{2,3}$ Maureen Riedl,, ${ }^{3}$ Pierre Charnet, ${ }^{1}$ \\ and Christopher M. Gomez ${ }^{2}$ \\ ${ }^{1}$ Centre de Recherches de Biochimie Macromoléculaire, Centre National de la Recherche Scientifique Unité Propre de \\ Recherche 1086, Montpellier, France 34293, and ${ }^{2}$ Center for Clinical and Molecular Neurobiology, Departments of \\ Neurology and Neuroscience, and ${ }^{3}$ Department of Neuroscience, University of Minnesota, Minneapolis, Minnesota 55455
}

\begin{abstract}
Spinocerebellar ataxia type 6 (SCA6) is a dominantly inherited degenerative disorder of the cerebellum characterized by nearly selective and progressive death of Purkinje cells. The underlying mutation in SCA6 consists of an expansion of a trinucleotide CAG repeat in the $3^{\prime}$ region of the gene, CACNA1A, encoding the $\alpha_{1 \mathrm{~A}}$ subunit of the neuronal P/Q-type voltage-gated calcium channel. Although it is known that this mutation results in an expanded tract of glutamine residues in some $\alpha_{1 \mathrm{~A}}$ splice forms, the distribution of these splice forms and the role of this mutation in the highly selective Purkinje cell degeneration seen in SCA6 have yet to be elucidated. Using specific antisera we demonstrate that the pathological expansion in SCA6 can potentially be expressed in multiple isoforms of the $\alpha_{1 \mathrm{~A}}$ subunit, and that these
\end{abstract}

isoforms are abundantly expressed in the cerebellum, particularly in the Purkinje cell bodies and dendrites. Using $\alpha_{1 \mathrm{~A}}$ subunit chimeras expressing SCA6 mutations, we show that the SCA6 polyglutamine expansion shifts the voltage dependence of channel activation and rate of inactivation only when expressed with $\beta_{4}$ subunits and impairs normal G-protein regulation of $P / Q$ channels. These findings suggest the possibility that SCA6 is a channelopathy, and that the underlying mutation in SCA6 causes Purkinje cell degeneration through excessive entry of calcium ions.

Key words: calcium channel; cerebellar ataxia; polyglutamine tract; Purkinje cell; $\beta$ subunit; neurodegenerative disease; channelopathy
Spinocerebellar ataxia type 6 (SCA6) is a dominantly inherited neurodegenerative disorder characterized by progressive gait ataxia, dysarthria, and incoordination caused by progressive cerebellar atrophy (Zhuchenko et al., 1997). Neuronal loss in SCA6 is limited almost exclusively to Purkinje cells (Gomez et al., 1997a; Sasaki et al., 1998; Takahashi et al., 1998; Ishikawa et al., 1999a). The underlying mutation in SCA6 consists of an expansion of a trinucleotide $\mathrm{CAG}$ repeat (CAG21-33) in exon 47 of the gene, CACNA1A, encoding the $\alpha_{1 \mathrm{~A}}$ subunit of the neuronal P/Q-type voltage-gated calcium channel (VGCC) (Zhuchenko et al., 1997; Yabe et al., 1998). The CAG repeat is in frame only in some splice forms of $\alpha_{1 \mathrm{~A}}$ where it codes for a polyglutamine tract in the $\mathrm{C}$ terminus (Zhuchenko et al., 1997). Nevertheless, from a genetic standpoint SCA6 belongs to the class of neurodegenerative disorders in which the pathological mutation encodes a protein possessing an expanded polyglutamine tract (Anonymous, 1993; Orr et al., 1993; Kawaguchi et al., 1994; David et al., 1997). These disorders are thought to result from the intranuclear accumulation of ubiquitinated aggregates of the expanded polyglutamine proteins and to have little to do with the function of the native protein (Paulson et al., 1997; Skinner et al., 1997; Becher et al., 1998; Cummings et al., 1998; Li and Li, 1998). Recently nonubiquitinated, intracytoplasmic aggregations of $\alpha_{1 \mathrm{~A}}$ subunits have been detected in brains of SCA6 patients using antisera to the $\alpha_{1 \mathrm{~A}}$ subunit, suggesting a role for aggregates in SCA6 that may differ from that in other disorders (Ishikawa et al., 1999b).

\footnotetext{
Received March 3, 2000; revised June 7, 2000; accepted June 9, 2000.

This work was supported by National Institutes of Health Grants RO1 NS37211 and RO1 NS36809 (C.M.G.), NATO Grant CRG 972059, Association Francaise contre les Myopathies, Association pour la Recherche contre le Cancer, Ligue Nationale contre le Cancer (P.C.), and Groupement de Reflexion sur la Recherche Cardio-Vasculaire (S.R.).

Correspondence should be addressed to Dr. Christopher M. Gomez, Box 295 , Center for Clinical and Molecular Neurobiology, Departments of Neuroscience and Neurology, University of Minnesota, 420 Delaware Street Southeast, Minneapolis, MN 55455. E-mail: gomez001@tc.umn.edu.

Copyright (C) 2000 Society for Neuroscience $0270-6474 / 00 / 206394-10 \$ 15.00 / 0$
}

Other episodic or progressive neurological or muscle disorders arise as a direct result of the pathological change in ion channel function produced by mutations in the gene encoding the channel protein (Barchi, 1998; Boonyapisit et al., 1999; Cooper and Jan, 1999). Missense mutations or mutations that predict a truncated protein have been found in the CACNA1A gene in families with episodic or progressive ataxia and hemiplegic migraine (Ophoff et al., 1996; Yue et al., 1997; Denier et al., 1999; Jen, 1999; Tournier, 1999) and in several mouse neurological mutants (Fletcher et al., 1996; Dove et al., 1998; Wakamori et al., 1998; Mori et al., 1999; Wakamori et al., 1999; Zwingman et al., 1999). Thus, rather than relating to the ability of the mutant proteins to form aggregates, the pathogenesis of SCA6 may relate to the effect of the mutation on the function of the P/Q-type calcium channel, making SCA6 a member of the class of disorders called "channelopathies." This distinction may be artificial, however, because the processes of aggregate formation and ion channel disturbance may be causally related.

Using antisera specific for the alternatively spliced exon 47, along with chimeric $\alpha_{1 \mathrm{~A}}$ subunits expressing the SCA6 mutation, we investigated whether there is restricted expression of exon 47encoded P/Q-type channels and the functional consequences of the SCA6-associated mutation. We show here that (1) the pathological expansion can be potentially expressed in multiple isoforms of the $\alpha_{1 \mathrm{~A}}$ subunit; (2) the exon 47-encoded polyQ tract is abundantly expressed in Purkinje cells; and (3) heterologous expression of chimeric $\alpha_{1 \mathrm{~A}}$ cDNA harboring wild-type or SCA6-associated polyglutamine tract in exon 47 , together with putative cerebellar auxiliary subunits $\left(\alpha_{2}-\delta\right.$ and $\beta_{2}, \beta_{3}$, or $\left.\beta_{4}\right)$, reveals a $\beta$ subunit-specific alteration in the electrophysiological properties of SCA6-mutant $\mathrm{P} / \mathrm{Q}$ channels.

\section{MATERIALS AND METHODS}

Preparation of antipeptide antisera. Rabbits were immunized with the bovine thyroglobulin-conjugated peptides CT1 (STSGTSTPRRGRRQLPA), corresponding to a sequence 24 amino acids $\mathrm{N}$-terminal to the polyQ tract in the long isoform of the $\alpha_{1 \mathrm{~A}}$ subunit (Zhuchenko et al., 1997), and 2L2 
(SELQQREHAPPREHA), which is the mouse homolog of CNA3 (Sakurai et al., 1996) (differing from rat in two amino acids). Peptides were conjugated to bovine thyroglobulin (Sigma, St. Louis, MO) using glutaraldehyde. The conjugated peptide $(1 \mathrm{mg} / \mathrm{ml})$ was emulsified with an equal volume of Freund's complete adjuvant (Difco, Detroit, MI) and injected into four New Zealand White rabbits. Subsequent injections were performed every 2 weeks using an equal volume of conjugated peptide and Freund's incomplete adjuvant. Rabbit sera were screened for antibody activity 1 week after the fourth and each subsequent injection.

Western blotting. pQE31-mCT (a gift from Colin Fletcher, Mammalian Genetics Laboratory) consists of a $510 \mathrm{bp}$ Msp fragment beginning from codon 15 of exon 47 of the mouse $\alpha_{1 \text { A }}$ gene to 79 bases past the second stop codon in exon 47 inserted into the 6xHis vector pQE31 (Qiagen, Hilden, Germany). To perform immunoblots on bacterial proteins, bacterial cell lysates from Escherichia coli transformed with pQE31-mCT were eluted from nickel-nitrilotriacetic acid (NTA) columns according to the manufacturer's instructions (Qiagen). Eluted proteins were separated by SDSPAGE and electrotransferred to nitrocellulose membranes.

To prepare crude membrane extracts, $0.1-0.2$ gm of mouse cerebellum or forebrain was homogenized for $5 \mathrm{sec}$ on ice in $2 \mathrm{ml}$ of extraction buffer [Tris-buffered saline (TBS), $\mathrm{pH}$ 7.4, 1\% Triton X-100, 10 mm EDTA, 10 mM EGTA, $50 \mu \mathrm{g} / \mathrm{ml}$ antipain, $2 \mu \mathrm{g} / \mathrm{ml}$ aprotinin $2,50 \mu \mathrm{g} / \mathrm{ml}$ chymotrypsin, $0.5 \mu \mathrm{g} / \mathrm{ml}$ leupeptin, $0.7 \mu \mathrm{g} / \mathrm{ml}$ pepstatin (Roche Molecular Biochemicals, Mannheim, Germany), $0.1 \mathrm{mg} / \mathrm{ml}$ calpain inhibitor I, and $0.05 \mathrm{mg} / \mathrm{ml}$ calpain inhibitor II ] at a speed of 7 in a tissue homogenizer (Polytron; Brinkman, Westbury, NY) and centrifuged $150,000 \times g$ for $1 \mathrm{hr}$ at $4^{\circ} \mathrm{C}$ in an SW28 rotor (Beckman Instruments, Palo Alto, CA). Ten micrograms of affinity-purified antipeptide antibody were added to $1 \mathrm{ml}$ of supernatant, followed by $50 \mu \mathrm{l}$ of washed staphylococcal protein A-agarose (Life Technologies, Gaithersburg, MD). After shaking gently overnight at $4^{\circ} \mathrm{C}$ on a tilting mixer, the complexes were centrif uged at $1300 \times g$ and washed three times with $600 \mu \mathrm{l}$ of TBS and $1 \%$ Triton X-100 and once with $200 \mu \mathrm{l}$ of 10 mM Tris, $\mathrm{pH} 7.4$, and $1 \%$ Triton $\mathrm{X}-100$. The proteins were denatured and extracted from the pellet by incubation at $70^{\circ} \mathrm{C}$ for $10 \mathrm{~min}$ in $20 \mu \mathrm{l}$ of load buffer (190 mM Tris, pH 6.8, $30 \mathrm{~mm}$ DTT, $7.5 \%$ SDS, $15 \%$ sucrose, and $0.01 \%$ bromphenol blue), subjected to SDS-PAGE electrophoresis in $6 \%$ gels, and electrotransferred at $24 \mathrm{~V}$ to nitrocellulose membranes $(0.45 \mu \mathrm{M})$ for $3 \mathrm{hr}$ in prechilled transfer buffer. Membranes were blocked overnight at $4^{\circ} \mathrm{C}$ in block solution (TBS, $0.5 \%$ Tween $20,5 \%$ dry milk, and $0.5 \%$ normal goat serum)

For immunoblotting membranes were reacted with primary antibody at $0.01 \mathrm{mg} / \mathrm{ml}$ from $2 \mathrm{hr}$ to overnight at $4^{\circ} \mathrm{C}$ and washed three times for $10 \mathrm{~min}$ each in block solution. Membranes were reacted with horseradish peroxidase-conjugated goat anti-rabbit Ig (Amersham Pharmacia Biotech, Arlington Heights, IL) diluted 1:6000 in block solution at room temperature for $2 \mathrm{hr}$, washed three times for $10 \mathrm{~min}$ each in block solution (minus proteins), and washed twice for $30 \mathrm{~min}$ each in TBS. To generate chemiluminescent signal, membranes were incubated $4 \mathrm{~min}$ in chemiluminescent substrate (Supersignal; Pierce, Rockford, IL), blotted dry, and exposed to film. To strip membranes for reprobing, blots were incubated in a solution of $100 \mathrm{~mm} \beta$-mercaptoethanol, $60 \mathrm{~mm}$ Tris, $\mathrm{pH} 8$, and $2 \%$ SDS at $55^{\circ} \mathrm{C}$ with gentle rocking and then rinsed in TBS.

Immunohistochemical localization. Male adult Sprague Dawley rats (100-150 gm; Harlan, Madison, WI) were anesthetized with an overdose of a sodium pentobarbital $(60 \mathrm{mg} / \mathrm{kg})$ and fixed by transcardial perfusion with calcium-free Tyrode's solution followed by fixative (4\% paraformaldehyde and $0.2 \%$ picric acid in $0.1 \mathrm{M}$ phosphate buffer, $\mathrm{pH} 6.9$ ) and finally with $10 \%$ sucrose in PBS, pH 7.2. The brain was dissected and stored overnight in $10 \%$ sucrose at $4^{\circ} \mathrm{C}$. Tissue sections were cut on a cryostat at $14 \mu \mathrm{m}$ thickness and mounted onto gel-subbed slides. Slides were incubated for $10 \mathrm{~min}$ at $92^{\circ} \mathrm{C}$ in antigen retrieval solution, $\mathrm{pH} 7.0$ (provided by Alex Kalyuzhny, R \& D Systems, Minneapolis, MN), rinsed in PBS, and immediately prepared for immunostaining. Sections were preincubated in a humidified chamber in blocking buffer $(0.3 \%$ Triton X-100, $1 \%$ BSA, and $1 \%$ normal donkey serum in PBS) for $30 \mathrm{~min}$ at room temperature and then incubated in primary antibody [anti-CT1, 1:500; anti-2L1 (CNA1), 1:500 (Alomone Labs, Jerusalem, Israel); anti-calbindin, 1:500 (Sigma); and anti-NF200, 1:1500 (Sigma)] overnight at $4^{\circ} \mathrm{C}$. After thorough rinsing in PBS, sections were incubated in species-specific secondary antibody (Cy3-conjugated, 1:200; Jackson ImmunoResearch, West Grove, PA) for $1 \mathrm{hr}$ at room temperature. Absorption controls were performed by preincubating the primary antisera with the peptide used in raising the antiserum at a concentraion of $10 \mu \mathrm{M}$. Images were obtained using the BioRad MRC-1000 confocal imaging system (BioRad Microscience Division, Cambridge, MA) and printed using a Fuji (Tokyo, Japan) Pictography 3000 printer.

Assembly of $\alpha_{1 A}$ chimeras. Rabbit-human chimeric $\alpha_{1 \mathrm{~A}}$ subunits were assembled using an overlap PCR strategy with human and rabbit cDNA and human genomic DNA as template. All amplifications were performed using a thermostable polymerase mixture that reduces errors by a proofreading function (Advantage PCR; Clontech, Cambridge, UK). Each amplified component was subcloned into the plasmid vector pGEMT (Promega, Madison, WI), and its sequence was verified by nucleotide sequence analysis. PCR was used to obtain cDNA correctly spliced for translation of exon 47 from the $3^{\prime}$ region of the human wild-type $\alpha_{1 \text { A }}$ subunit. A $150 \mathrm{bp}$ product was amplified from pooled cDNA constructed from a human cerebellar RNA (Marathon Ready cDNA; Clontech) using forward primer A (AGCGCTGGTCCCGCTCGCCCAGCG), corresponding to a conserved sequence near the $3^{\prime}$ end of exon 46 , and reverse primer B (GGGGGTCTGGGGGAGCTGGC), corresponding to a position $66 \mathrm{bp}$ upstream of the CAG repeat. A clone, pTail-U, was selected that contained the added five-nucleotide GGCAG sequence. The $680 \mathrm{bp}$ lower half of the cDNA tail was amplified using forward primer C (GCCAGCTCCCCCAGACCCCC), complementary to primer B, and reverse primer D (CGATGATTGGTGCTAAGCCCGGGCGAGG), corresponding to the end of the human $\alpha_{1 \mathrm{~A}}$ subunit cDNA, and subcloned (pTail-Ln). This region contains the polymorphic CAG repeat, which was identified as a CAG13 allele in the human cDNA by dideoxy sequence analysis (pTail-L13). Distinct pathological CAG repeat alleles of 22, 26, and 30 repeats were amplified from genomic DNA of SCA6 patients using forward primer C (GCCAGCTCCCCCAGACCCCC) and reverse primer S-5-R1 (TGGGTACCTCCGAGGGCCGCTGGTG) (Zhuchenko et al., 1997) and inserted in place of the CAG13 allele in pTail-L13 by a unique KpnI restriction site. Full-length cDNA tails, $\sim 800 \mathrm{bp}$ in length and containing each allele, were assembled by overlap PCR using primers A and D and templates pTail-U and pTail-Ln and subcloned to generate pCT(CAG)n. Except for the different length of the CAG repeat stretch, the $3^{\prime}$ cDNA, pCT(CAG)n, sequence is $100 \%$ identical to the published region of the human $\alpha_{1 \mathrm{~A}}$ cDNA clone and consists of $29 \mathrm{bp}$ of exon 46 and the entire exon 47 (Ophoff et al., 1996; Zhuchenko et al., 1997).

The $\mathrm{pCT}(\mathrm{CAG}) \mathrm{n}$ tails were attached to the functional rabbit $\alpha_{1 \mathrm{~A}}$ subunit cDNA, BI-1 (psp72 plasmid backbone, a gift from Y. Mori; Mori et al., 1991), by means of overlap PCR, followed by restriction digestion and ligation. The full-length $\mathrm{CT}(\mathrm{CAG}) \mathrm{n}$ tails were amplified using primers $\mathrm{A}$ and $\mathrm{D}$ and each pCT(CAG)n as template. A 685 bp $3^{\prime}$ region (BI-1-CT), corresponding to the $3^{\prime}$ end of the rabbit BI- 1 cDNA, was amplified using forward primer E (CCATCCTGGGTGACCCAGCG) and reverse primer F (complementary to primer A). The 1470 bp overlap PCR product consisting of the product, BI-1-CT, conjoined to $\mathrm{CT}(\mathrm{CAG}) \mathrm{n}$ was then produced by PCR using primers E and D and BI-1-CT and CT(CAG)n as templates. This chimeric rabbit human $3^{\prime}$ cDNA PCR product was then substituted for the rabbit BI-1 3' region by means of the common restriction site BstEII. The proper assembly of the final chimeric products was confirmed by dideoxy nucleotide sequence analysis. RNA was transcribed in vitro from the BamHI-linearized $\alpha_{1 \mathrm{~A}}$ chimeras.

Electrophysiological recordings. Xenopus oocyte preparation and injection $\left(20-40 \mathrm{nl}\right.$ of $\alpha_{1}$ plus $\alpha_{2}-\delta$ plus $\beta$ cRNA at $\left.0.3 \mathrm{ng} / \mathrm{nl}\right)$ were performed as described elsewhere (Cens et al., 1999). For the G-protein study a mixture of $\alpha \mathrm{G} 0$ and $\mu$-opioid receptor cRNA, both at $1 \mu \mathrm{g} / \mu \mathrm{l}$, was injected with three volumes of the $\mathrm{Ca}^{2+}$ channel cRNA. The $\mu$-opioid receptor cDNA in the plasmid pBluescript (Stratagene, La Jolla, CA) was linearized with $\mathrm{Xba \textrm {I }}$; the $\alpha \mathrm{G} 0 \mathrm{cDNA}$ (gifts from C. Labarea and L. Yue, Caltech) in pGEM was linearized with NheI; and both were transcribed with T7 polymerase. Oocytes were then incubated for $2-7 \mathrm{~d}$ at $19^{\circ} \mathrm{C}$ under gentle agitation before recording. Whole-cell $\mathrm{Ba}^{2+}$ currents were recorded under two-electrode voltage clamp using the GeneClamp 500 amplifier (Axon Instruments, Burlingame, CA). Current and voltage electrodes (resistance $<1 \mathrm{M} \Omega$ ) were filled with electrode solution $(2.8 \mathrm{M} \mathrm{CsCl}$ and $10 \mathrm{~mm}$ BAPTA, adjusted to $\mathrm{pH} 7.2$ with $\mathrm{CsOH}) . \mathrm{Ba}^{2+}$ current recordings were performed after injection of BAPTA solution [one or two 40-70 msec injections at 1 bar, $100 \mathrm{~mm}$ BAPTA-free acid (Sigma), $10 \mathrm{~mm} \mathrm{CsOH}$, and $10 \mathrm{~mm}$ HEPES, $\mathrm{pH}$ 7.2]. The composition of the recording solution was 10 $\mathrm{mm} \mathrm{BaOH}, 20 \mathrm{~mm}$ TEAOH, $50 \mathrm{~mm} N$-methyl-D-glucamine, $2 \mathrm{~mm} \mathrm{CsOH}$, and $10 \mathrm{~mm}$ HEPES, adjusted to $\mathrm{pH} 7.2$ with methanesulfonic acid. Only oocytes expressing $\mathrm{Ba}^{2+}$ currents with amplitudes in the range of $0.5-3 \mu \mathrm{A}$ were analyzed to ensure sufficient resolution and avoid voltage-clamp problems. Currents were filtered and digitized using a DMA-Tecmar labmaster and subsequently stored on a personal computer by using version 6.02 of the pClamp software (Axon Instruments). $\mathrm{Ba}^{2+}$ currents, recorded during a typical test pulse from -80 to $+10 \mathrm{mV}$ of $2.5 \mathrm{sec}$ duration, were well fitted using a biexponential function: $i(t)=\left(A_{1} * \exp \left(-(t-K) / \tau_{1}\right)+\right.$ $\left.A 2 * \exp \left(-(t-K) / \tau_{2}\right)\right)+C$, where $t$ is the time, $K$ is the zero time, $A_{1}, A_{2}$, $\tau_{1}$, and $\tau_{2}$ are the amplitudes and time constants, respectively, of the two exponential components, and $C$ is the fraction of noninactivating current. Current amplitudes and inactivation time constants were measured using Clampfit (pClamp version 6.02; Axon Instruments). Pseudo-steady-state inactivation curves (2.5 $\mathrm{sec}$ of conditioning depolarization) were fitted using the equation $I / I_{\max }=R+(1-R) /\left(1+\exp \left(\left(V-V_{0.5}\right) / k\right)\right)$, and $I-V$ curves were fitted using the equation $I / I_{\max }=g *\left(V-E_{\mathrm{rev}}\right) /[1+\exp ((V-$ $\left.\left.V_{0.5}\right) / k\right)$, where $g$ is a normalized conductance, $E_{\text {rev }}$ is the extrapolated reversal potential for $\mathrm{Ba}^{2+}, k$ is the slope factor, $V_{0.5}$ is the potential for half-inactivation or activation, $V$ is the conditioning depolarization for inactivation curves or the membrane potential used to record current for $I-V$ curves, and $R$ is the proportion of noninactivating current. All values are presented as the mean \pm SD. The significance of the difference between two means was tested using the Student's $t$ test $(p<0.05)$. All chemicals were from Sigma. D-Ala2, $N$-Me-Phe4, Gly-ol5 (DAMGO) was purchased from Research Biochemicals (Natick, MA) and prepared daily at the desired concentration $(10 \mu \mathrm{M})$. 


\section{RESULTS}

\section{The long exon $47 \alpha_{1 A}$ sequence is highly expressed in multiple $\alpha_{1 \mathrm{~A}}$ isoforms in cerebellum}

To investigate the distribution of exon 47-encoded $\alpha_{1 \text { A }}$ polypeptides and to determine whether their restricted expression could explain the cell selectivity of the neurodegeneration in SCA6, we generated antisera specific for this domain and characterized their reactivity to proteins immunoprecipitated with other anti- $\alpha_{1 \mathrm{~A}}$ antisera defined in Figure $1 \mathrm{~A}$. The $\mathrm{C}$-terminal antiserum reacted with a highly conserved epitope, CT1, 24 residues $\mathrm{N}$-terminal to the predicted polyglutamine tract in the human $\alpha_{1 \mathrm{~A}}$ and present in the mouse and rabbit $\mathrm{C}$ terminus (Zhuchenko et al., 1997). Figure $1 B$ demonstrates reactivity of the anti-CT1 antibody to a 6xHis-tagged fusion protein constructed from the mouse cDNA encoding the $\mathrm{C}$ terminus inserted into the $6 \mathrm{xHis}$ vector pQE31. The anti-CT1 antiserum reacted with a single species present in transfected bacterial proteins eluted from a Ni-NTA-agarose column (lanes 2, 4). The protein detected corresponds well to the predicted molecular weight of $12 \mathrm{kDa}$ and was also detected by antiserum to the RGS6xHis tag (lane 1). Binding to the $\mathrm{CT} 1$ epitope was blocked by incubation in CT1 peptide (lane 3 ).

To identify brain $\alpha_{1 \mathrm{~A}}$ polypeptides, we analyzed proteins immunoprecipitated from detergent extracts (Fig. 1C) of forebrain (lane 1) or cerebellum (lanes 2-9) by SDS-PAGE and immunoblotting using antipeptide antibodies. In lanes $1-4, \alpha_{1 \mathrm{~A}}$ polypeptides were immunoprecipitated using antibody to $2 \mathrm{~L} 1,2 \mathrm{~L} 2$, and CT1 and reacted with anti-CT1 antibody. 2L1, equivalent to CNA1 (Westenbroek et al., 1995), and 2L2, the mouse homolog of CNA3 (Sakurai et al., 1995, 1996), correspond to sequences found in the $\mathrm{L}_{\text {II-III }}$ cytoplasmic loop of $\alpha_{1 \mathrm{~A}}$. Although much less abundant in immunoprecipitates from other regions, CT1 antiserum appeared to detect the same pattern of isoform sizes in forebrain (lane 1) and spinal cord (data not shown). Lanes 5-7 correspond to lanes 2-4 after the blot was stripped and reacted with antibody to 2L1 (CNA1). As has been noted previously for lectin-purified $\alpha_{1 \mathrm{~A}}$ polypeptides, anti-2L1 reacts with polypeptides ranging in size from $<160$ to $>200 \mathrm{kDa}$ (lane 5). The larger sizes isolated than seen previously may relate to the simple one-step extraction procedure. Surprisingly, rather than reacting with a single $\alpha_{1 \mathrm{~A}}$ isoform, the anti-CT1 antiserum binds to a range of polypeptides precipitated by anti-2L1 (lanes 1,2 ) that is similar to the pattern recognized by $2 \mathrm{~L} 1$ (lane 5 ).

Anti-2L2 (equivalent to CNA3), which reacts with a subset of CNA1-expressing $\alpha_{1 \mathrm{~A}}$ isoforms (Sakurai et al., 1995, 1996), immunoprecipitates several polypeptides that also bear the CT1 epitope (Fig. 1C, lane 3). The anti-CT1 antisera was less efficient at precipitating the $\alpha_{1 \mathrm{~A}}$ polypeptides. Moreover, both this antibody and the anti-2L2 (CNA3) precipitate $140 \mathrm{kDa}$ isoforms apparently lacking the 2L1 (CNA1) epitope (lanes 3, 4). These results are consistent with those of Northern blot analysis (Zhuchenko et al., 1997) of cerebellar $\alpha_{1 \mathrm{~A}}$ transcripts and studies of other $\alpha_{1}$ subunits (Sakurai et al., 1995; Lin et al., 1997) and further indicate that alternative splicing leads to a great diversity of $\alpha_{1 \mathrm{~A}}$ isoforms. Thus, the extended exon 47 sequence, which in humans encodes the polyglutamine tract, is present on multiple $\alpha_{1 \mathrm{~A}}$ isoforms.

\section{The long exon $47 \alpha_{1 \mathrm{~A}}$ sequence is expressed heavily in cerebellar Purkinje cells and in neurons throughout the nervous system}

To investigate the sites of expression of the long exon $47 \alpha_{1 \mathrm{~A}}$ isoforms, we studied the pattern of anti-CT1 binding by immunohistochemistry (Fig. 2) and compared this with the pattern seen with anti-2L1(CNA1). In the cerebellum anti-CT1 stained the Purkinje cell soma and dendrites intensely (Fig. 2A,B,I,J). Staining was also seen in a smaller population of cells in the molecular layer and more faintly in the granule cell layer. This pattern was similar to that seen in human cerebellar cortex using RNA probes consisting of the exon 46-47 sequence (Ishikawa et al., 1999b). The prominent immunoreactivity within Purkinje cell bodies and prox-
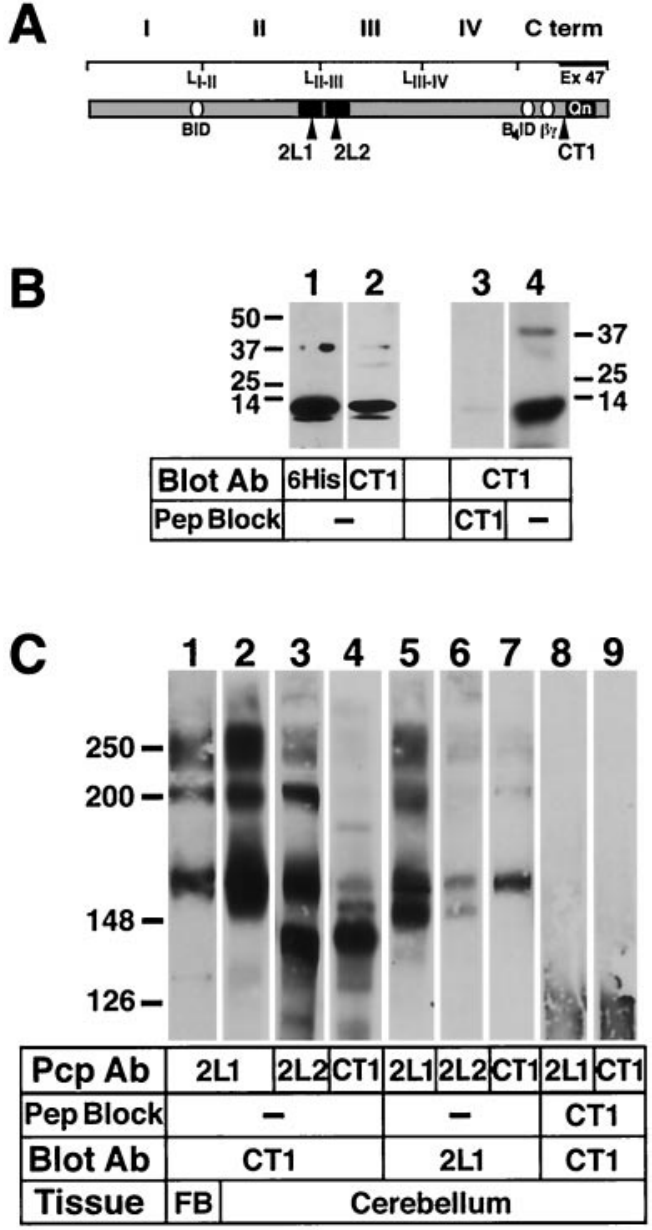

Figure 1. A, Diagram of $\alpha_{1 \mathrm{~A}}$ subunit. The gray bar represents the $\alpha_{1 \mathrm{~A}}$ subunit. The approximate positions of the four repeat domains $(I-I V)$ and the $\mathrm{C}$ terminus $(C$ term $)$ are indicated on the line above. The positions of the cytoplasmic loop domains $L_{I-I I}, L_{I I-I I}$, and $L_{I I I-I V}$ and the extended exon 47 (heavy line) are indicated below the line. The primary $\beta$ interaction domain (in the $\mathrm{L}_{\mathrm{I}-\mathrm{II}}$ domain), the $\beta_{4}$ interaction domain (in the $\mathrm{C}$ terminus), and the G-protein $\beta-\gamma$ interaction domain (in the $C$ terminus) are indicated as white ovals on the gray bar within the indicated domains. The polyglutamine tract $(Q n)$ is located within the elongated exon 47 region. The epitopes for 2L1 and $2 \mathrm{~L} 2$ (black arrows) are indicated as black boxes within the $\mathrm{L}_{\mathrm{I}-\mathrm{II}}$ domain. The epitope for CT1 (black arrow) is within the extended exon 47 region immediately adjacent to the polyglutamine tract $(Q n)$. The sites of other $\mathrm{G}$-protein and $\mathrm{Ca}^{2+}$-calmodulin kinase interaction domains have been excluded for clarity of presentation. $B$, Antibody to exon 47-encoded peptide reacts with recombinant mouse $\alpha_{1 \mathrm{~A}}$ fusion proteins. The mouse $\mathrm{C}$ terminus 6xHis-tagged fusion protein was subjected to $10 \%$ SDS-PAGE, transferred to a nitrocellulose membrane, and probed with antibody to the RGS-6xHis tag (lane 1). The blot was subsequently stripped and reprobed with rabbit antibody to the CT1 (lane 2). A single prominent band is seen at the predicted size of $12 \mathrm{kDa}$ in both reactions. Preincubation of the membrane with an excess of CT1 peptide (lane 3) blocked binding of anti-CT1 compared with no peptide in same experiment (lane 4). $C$, Multiple $\alpha_{1 \mathrm{~A}}$ isoforms express the long exon 47 sequence. Shown are immunoblots of immunoprecipitated proteins from membrane extracts of mouse forebrain (FB, lane 1) and cerebellum (lanes 2-9). For immunoprecipitation, 2\% Triton X-100 extracts were treated with affinitypurified rabbit antibody to CT1 peptide (anti-CT1), anti-2L1 (CNA1), or anti-2L2 (CNA3), followed by staphylococcal protein A-agarose, as indicated $(P c p A b)$, and separated by electrophoresis in 6\% polyacrylamide gels. Blots $(B l o t A b)$ were incubated with anti-CT1 and peroxidase-conjugated anti-rabbit Ig and developed with SuperSignal (Pierce). This blot was then stripped and reincubated with anti-2L1 and treated as above. On the CT1 blot, isoforms ranging from $<140$ to $250 \mathrm{kDa}$ can be identified. The exon 47-positive isoforms in forebrain (lane 1) appear identical to, although less abundant than, those in cerebellum (lane 2). The anti-CT1 antiserum (lane 4) is less efficient at precipitating the high molecular weight isoforms than are anti-2L1 and anti2L2 (lanes 2, 3), although the CT1 epitope is apparently detected on these polypeptides when precipitated by anti-2L1 or anti-2L2 (lanes 2, 3). Reprobing of the anti-CT1-probed immunoblot of cerebellar proteins with anti-2L1 after stripping (lanes 5-7) reveals the same bands at 160,220 , and $250 \mathrm{kDa}$. Detection of these proteins is completely inhibited when the anti-CT1 antiserum is preincubated with CT1 peptide (lanes 8, 9). Exposure times: lane 1, 1 min; lanes 2-5, 1-2 sec; lane 6, $15 \mathrm{sec}$; lane 7, 5 min; lanes 8 and 9, 2 min. 

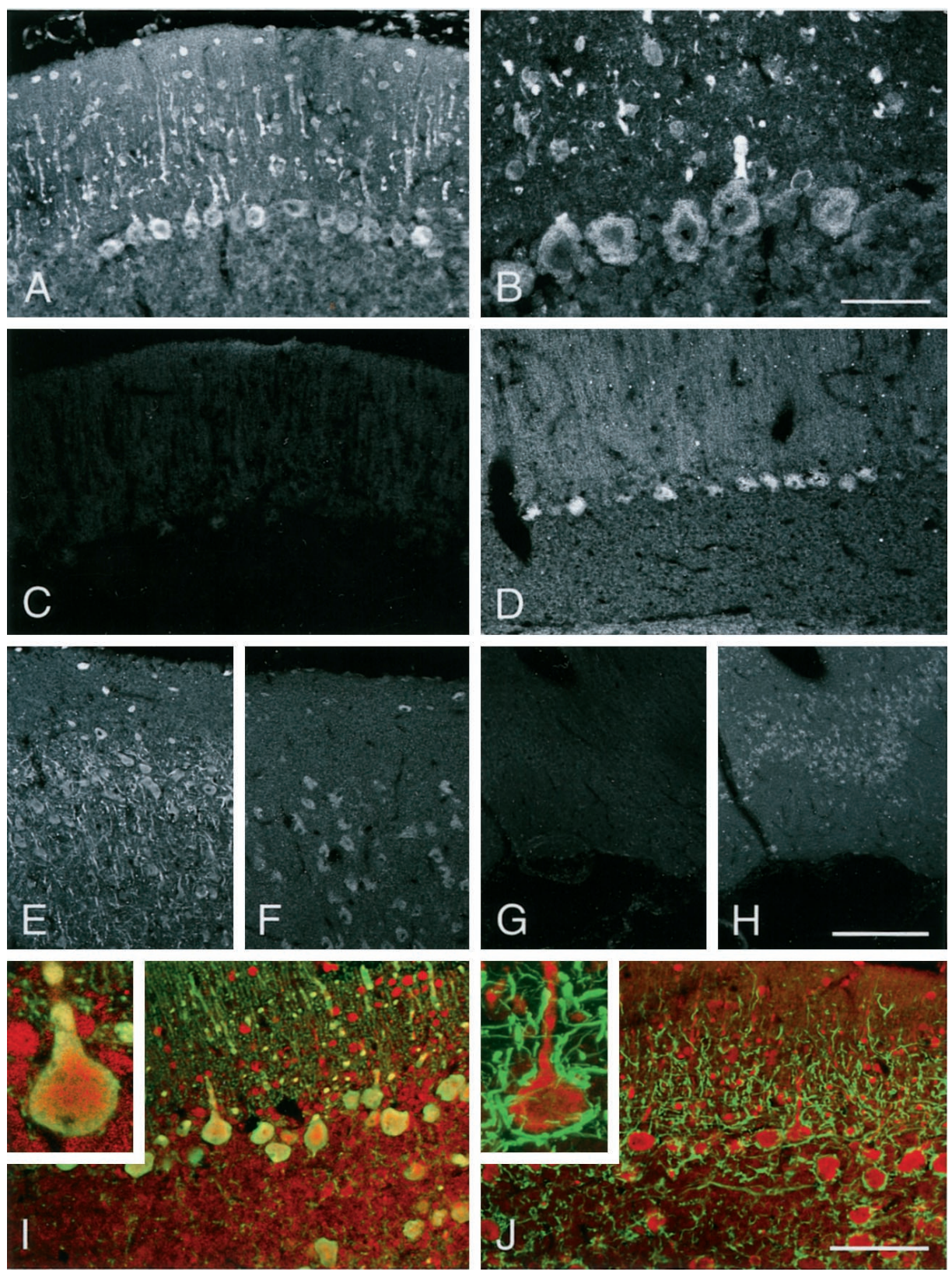

Figure 2. The long exon 47 -encoded $\alpha_{1 \mathrm{~A}}$ splice form is abundant in cerebellar Purkinje cells and is present in other neocortical neurons. Confocal images of rat cerebellum $(A-D, I, J)$, neocortex $(E, F)$, and piriform cortex $(G, H)$ are from sections immunolabeled with anti-CT1 $(A-C, E$, $G, I, J$ ) or anti-2L1 (equivalent to CNA1; Sakurai et al., 1996; $D, F, H$ ) and double-labeled with anti-calbindin $(I)$ or anti-NF200 $(J)$. Anti-CT1 labels the Purkinje cell soma and dendrites intensely $(A, B, I, J)$. Higher magnification reveals punctate staining within the cell body and primary dendrite of these neurons $(B)$ that colocalizes with calbindin in the cerebellum $(I)$. Anti-CT1 also stains a small population of cells in the molecular layer of the cerebellum $(A, I, J)$. Staining is blocked by preabsorption of the antiCT1 with CT1 peptide $(C)$. In the cerebellar cortex the anti-2L1 antibody shows a similar pattern of staining in the Purkinje cells, although the dendrites are stained less intensely $(D)$. In neocortex anti-CT1 $(E)$ and anti-2L1 $(F)$ labeled cortical neurons. In other areas, such as piriform cortex, cortical neurons were labeled by anti-2L1 $(H)$, whereas there was no staining by anti-CT1 $(G)$. Staining by anti-2L1 was blocked by preincubation in 2L1 peptide (data not shown). Colocalization of anti-CT1 (red) and calbindin ( green) confirmed the localization of CT1 antigen to Purkinje cells and proximal dendrites, as well as what appear to be interneurons in the molecular layer $(I, J)$. This is confirmed by the absence of co-localization between CT1 (red) and NF200 ( $J$, green). Scale bars: $A, C-J, 100 \mu \mathrm{m} ; B, 40 \mu \mathrm{m}$. imal dendrites is highly reminiscent of those patterns seen with other antisera to $\alpha_{1 \mathrm{~A}}$ subunits, including anti-CNA1 (Westenbroek et al., 1995; Sakurai et al., 1996). In our hands anti-CNA1 (2L1 in the current nomenclature) strongly stained the Purkinje cells, but the dendritic staining was less prominent, presumably because of differences in fixation, antigen retrieval method, and antiserum lot (Fig. 2D). Immunostaining by both anti-CT1 (Fig. 2C) and anti2L1 (data not shown) were blocked by preincubation in the specific peptide.

The pattern of immunostaining with anti-CT1 differs from that of anti-2L1 (CNA1) regionally. Some areas, such as regions of the neocortex, were labeled by both antisera with patterns similar to those seem in cerebellum (Figure $2 E, F$ ). In contrast, numerous other areas, such as the thalamus, the preoptic area, and the piriform cortex, exhibited no immunostaining by anti-CT1 (Fig. $2 G)$, yet neurons of these areas were clearly labeled by anti-2L1 (Fig. 2H).

In co-localization studies there was strong overlap of the CT1 staining with that of calbindin in Purkinje cells, including in their primary dendrites and terminals (Fig. 2I). When double labeling was performed using anti-NF200, which labels basket cell fibers intensely, staining with anti-CT1 appeared to be confined to Purkinje cells and some interneurons but was not present in terminals that project to the Purkinje cell layer (Fig. 2J). These findings indicate that the long exon 47-encoded sequence (which encodes the SCA6-associated polyQ tract) is expressed abundantly in Purkinje cell bodies and dendrites and in some interneurons of the cerebellar cortex. Although these findings cannot account for the absolute selectivity of Purkinje cell death in SCA6, the prominent expression of the expanded polyQ tract in these cells may be a contributing factor to their selective degeneration (Gomez et al., 1997a; Sasaki et al., 1998; Ishikawa et al., 1999a).

\section{Polyglutamine expansions alter activation and inactivation kinetics of $P / Q$ channels}

To investigate the effect of the polyglutamine expansion on VGCC function, we expressed chimeric $\alpha_{1 \mathrm{~A}}$ cDNA with five different C-terminal configurations in Xenopus oocytes. The chimeric $\alpha_{1 \mathrm{~A}}$ cDNAs were assembled from the rabbit BI-1 cDNA (Mori et al., 1991) containing part of the sequence of the predicted rabbit exon 46 and the human cDNA encoding the last 29 amino acids of exon 
Table 1. Activation properties of $\alpha_{1 \mathrm{~A}}$ chimeras expressed in Xenopus oocytes

\begin{tabular}{|c|c|c|c|c|c|c|c|c|c|c|}
\hline $\begin{array}{l}\beta \text { subunit } \\
\text { subtype }\end{array}$ & $\begin{array}{l}\text { Exon } 47 \\
\text { allele }^{a}\end{array}$ & $V_{0.5}{ }^{b}$ & SD & $n^{c}$ & $k^{d}$ & SD & $n$ & $E_{\mathrm{rev}}^{e}$ & SD & $n$ \\
\hline \multirow[t]{5}{*}{$\beta_{2}$} & Q-30 & -11 & 5 & 13 & -5.2 & 0.8 & 8 & 50 & 3 & 13 \\
\hline & Q-26 & -11 & 3 & 12 & -4.0 & 0.7 & 8 & 47 & 2 & 12 \\
\hline & Q-20 & -6 & 2 & 5 & -6.7 & 0.2 & 5 & 50 & 2 & 5 \\
\hline & Q-13 & -9 & 4 & 12 & -4.5 & 0.8 & 8 & 47 & 2 & 11 \\
\hline & BI-1 & -10 & 4 & 6 & -4.1 & 0.2 & 4 & 48 & 1 & 6 \\
\hline \multirow[t]{5}{*}{$\beta_{3}$} & Q-30 & -4 & 2 & 10 & -3.6 & 0.6 & 10 & 49 & 8 & 10 \\
\hline & Q-26 & -7 & 3 & 11 & -3.3 & 0.4 & 11 & 48 & 3 & 11 \\
\hline & Q-20 & -7 & 4 & 10 & -3.5 & 0.4 & 10 & 48 & 5 & 10 \\
\hline & Q-13 & -4 & 4 & 14 & -3.9 & 0.3 & 14 & 52 & 4 & 14 \\
\hline & BI-1 & -7 & 4 & 10 & -3.8 & 0.4 & 10 & 50 & 2 & 10 \\
\hline \multirow[t]{5}{*}{$\beta_{4}$} & Q-30 & $-7^{f}$ & 4 & 12 & -4.1 & 0.9 & 12 & 53 & 3 & 10 \\
\hline & Q-26 & -5 & 3 & 8 & -3.8 & 0.4 & 7 & 50 & 2 & 10 \\
\hline & Q-20 & -1 & 1 & 9 & -4.9 & 0.3 & 9 & 47 & 2 & 9 \\
\hline & Q-13 & 0 & 5 & 7 & -4.5 & 0.6 & 7 & 50 & 8 & 7 \\
\hline & BI-1 & -2 & 2 & 8 & -4.9 & 1 & 7 & 55 & 1 & 10 \\
\hline
\end{tabular}

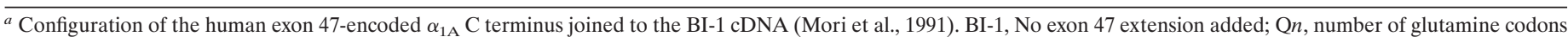
in the wild-type (Q-13) or SCA6 mutant (Q-22, -26, and -30 exon 47 alleles).

${ }^{b}$ Potential for half-activation $(\mathrm{mV})$.

${ }^{c}$ Number of oocytes.

${ }^{d}$ Slope factor.

${ }^{e}$ Extrapolated reversal potential for $\mathrm{Ba}^{2+}(\mathrm{mV})$.

${ }^{f}$ Significant at $p<0.05$.

46 and all of exon 47. Separate clones were derived from PCRamplified genomic DNA containing the wild-type allele with 13 glutamine residues (Q-13) or the SCA6-associated alleles with 22, (Q-22), 26 (Q-26), or 30 (Q-30) glutamine residues. RNA transcribed from the BI-1 plasmid or from plasmids bearing chimeric $\alpha_{1 \mathrm{~A}}$ subunits was co-injected with in vitro-transcribed RNA encoding $\alpha_{2}-\delta$ and either $\beta_{2}, \beta_{3}$, or $\beta_{4}$ subunits. All five $\alpha_{1 \mathrm{~A}}$ subunits yielded qualitatively normal voltage-activated currents.

We studied the effect of the wild-type and different polyQ SCA6-associated mutant alleles on $\mathrm{P} / \mathrm{Q}$ channel activation and inactivation using a paired pulse protocol. Results are summarized in Table 1 and Figure 3. Oocytes expressing the Q-30 $\alpha_{1 \mathrm{~A}}$ chimera and $\beta_{4}$ subunits had a significant shift of the point of half-maximal activation, EA0.5, $\left(\mathrm{EA} 0.5_{\mathrm{O}-30 / \beta_{4}}=-7 \pm 4 ; n=12\right.$; vs EA0.5 $\beta_{4}=0 \pm 5 ; n=7 ; p=0.005$; Fig. $3 A$ ). The oocytes expressing Q-26 and $\beta_{4}$ subunits also appeared to have a hyperpolarizing shift, although the change was not statistically significant. In contrast, there was no shift in EA0.5 when the same experiment was performed for the $\alpha_{1 \mathrm{~A}}$ chimeras co-expressed with $\beta_{2}$ subunits $\left(\mathrm{EA} 0.5_{\mathrm{Q}-30 / \beta_{2}}=-11 \pm 5 ; n=13\right.$; vs EA $0.5_{\mathrm{Q}-13 / \beta_{2}}=-9 \pm 4 ; n=$ 12; Fig. $3 B$ ) or $\beta_{3}$ subunits (EA0.5 $5_{\mathrm{Q}-30 / \beta_{3}}=-4 \pm 2 ; n=10$; vs $\mathrm{EA} 0.5_{\mathrm{Q}-13 / \beta_{3}}=-4 \pm 4 ; n=14$; data not shown).

We studied the time course of inactivation of $\mathrm{P} / \mathrm{Q}$ channels during $2.5 \mathrm{sec}$ voltage steps of $10 \mathrm{mV}$. Figure $4 A$ shows normalized traces of $\mathrm{P} / \mathrm{Q}$ channels expressing the BI- 1 isoform or the long $\alpha_{1 \mathrm{~A}}$ chimeras expressing Q-13, Q-22, Q-26, and Q-30 alleles in the presence of $\beta_{2}$ or $\beta_{4}$ subunits. Currents recorded in oocytes expressing the Q-30 allele $\alpha_{1 \mathrm{~A}}$ channel in the presence of the $\beta_{4}$ subunit were visibly prolonged, whereas channels expressing the Q-30/ $\beta_{2}$ combination were no different from the other $\alpha_{1 \mathrm{~A}}$ alleles. To compare the inactivation of each subunit combination quantitatively, we determined the percent of noninactivating current as the ratio of the residual current at the end of the pulse to the peak current at the beginning of the pulse (Fig. $4 B$ ). Q-30/ $\beta_{4}$ channels inactivate significantly more slowly than the other channels.

A kinetic analysis of the inactivation phases has shown that the time course of inactivation can be fit to two exponents, $\tau_{\text {fast }}$ and $\tau_{\text {slow }}$. Only the fast component is affected by the expanded polyQ $\left(\tau_{\text {fastQ-30 } / \beta_{4}}=166.4 \pm 27.1 ; n=7\right.$; vs $\tau_{\text {fastQ- } 13 / \beta_{4}}=135.5 \pm 13.5$; $n=7 ; p=0.005$; Fig. $5 A$ ). The fast component of the Q-30 channels also appears to be prolonged in the $\beta_{2}$-expressing chan- nels $\left(\tau_{\text {fastQ- } 30 / \beta_{2}}=205.8 \pm 114.9 ; n=10 ;\right.$ vs $\tau_{\text {fastBI- } 1 / \beta_{2}}=125.8 \pm$ $114.9 ; n=4 ; p=0.005)$. In the $\beta_{2}$ channels the slow component represents $\sim 99 \%$ of the current decay. This accounts for the lack of effect of the polyQ expansion on inactivation in $\beta_{2}$-expressing oocytes. In $\beta_{4}$-expressing channels, however, the slow component represents $\sim 30 \%$ of the current decay. The increase in $\tau_{\text {fast }}$ in Q-30/ $\beta 4$ channels leads to the slowed inactivation.

Although the effect on inactivation was statistically significant, it was important to estimate the potential impact of such a change in channel kinetics on the intracellular ionic milieu. Figure $5 B$ compares the proportion of $\mathrm{Ca}^{2+}$ entering the cell with a given activation of $\mathrm{P} / \mathrm{Q}$ channels of each type, as determined by the integral of the current traces over time. With a single event a significantly greater amount of $\mathrm{Ca}^{2+}$ enters the cell through Q-30/ $\beta_{4}$ channels than through wild-type or $\beta_{2}$ channels.

During normal cellular activity the effect of a reduced threshold for $\mathrm{P} / \mathrm{Q}$ channel activation in SCA6 Purkinje cells might potentially be blunted if the mutation also reduced channel reactivation. Therefore, we studied the effect of the elongated $\alpha_{1 \mathrm{~A}} \mathrm{C}$ terminus with normal and expanded polyQ tract on recovery from inactivation. To assess reactivation, the currents evoked by test pulses delivered at varying intervals after a conditioning pulse $(2.5 \mathrm{sec}$ at $10 \mathrm{mV}$ ) were plotted as a function of pulse interval. Figure $6 \mathrm{~A}$ shows typical current traces for oocytes expressing BI- 1 plus $\alpha_{2}-\delta$ plus $\beta_{4}$. The recovery time course was not significantly affected by $\alpha_{1 \mathrm{~A}}$ chimeras Q-13, Q-22, Q-26, and Q-30. Furthermore, because calcium channel activation occurs repetitively, we investigated the effect of the modified $\mathrm{P} / \mathrm{Q}$ channel $\mathrm{C}$ termini on the response to repetitive stimulation (Fig. $6 B$ ). $\mathrm{Ba}^{2+}$ currents were recorded during stimulation $(10 \mathrm{mV}, 1 \mathrm{~Hz})$, and the peak amplitude was plotted as a function of stimulus number. Current decay was assessed by determining the ratio of the amplitude of the 1st response to that of the 10th response $\left(I_{1} / I_{10}\right)$. No statistical differences in $I_{1} / I_{10}$ (at the $p=0.05$ level) were noted between current decay in BI-1 and normal (Q-13) or pathological (Q-22, Q-26, and Q-30) chimeric $\alpha_{1 \mathrm{~A}}$ subunits expressed with $\alpha 2-\delta$ and either $\beta_{4}$ or $\beta_{2}$.

\section{G-protein regulation of the long exon $47 \alpha_{1 \mathrm{~A}}$ subunit is abolished by the expanded polyQ tract}

There are at least two recognized G-protein interaction domains on $\alpha_{1 \mathrm{~A}}$ subunits, one in the cytoplasmic loop between repeat 
A
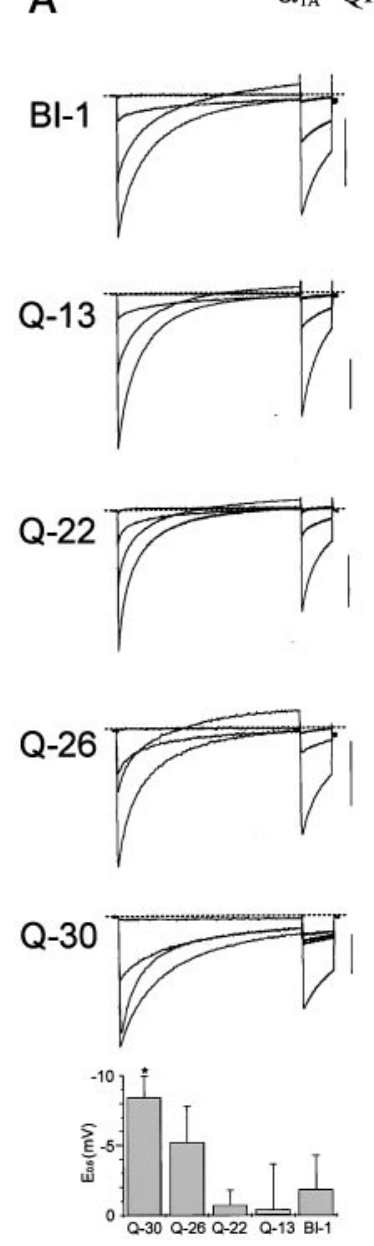
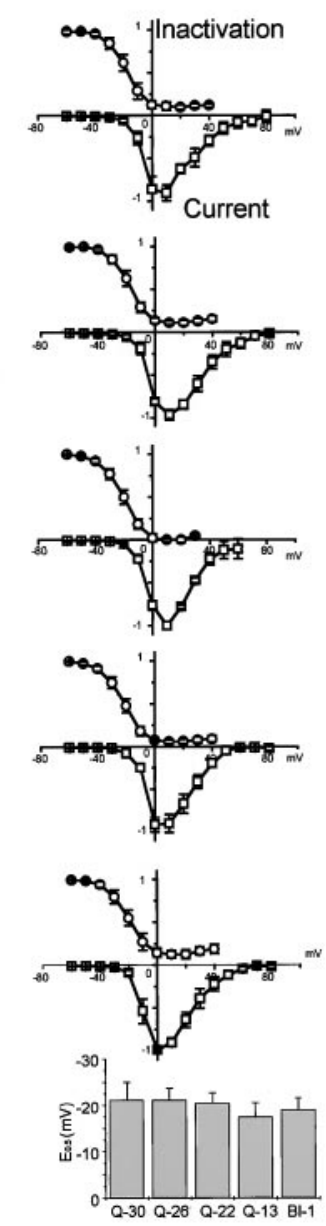

B
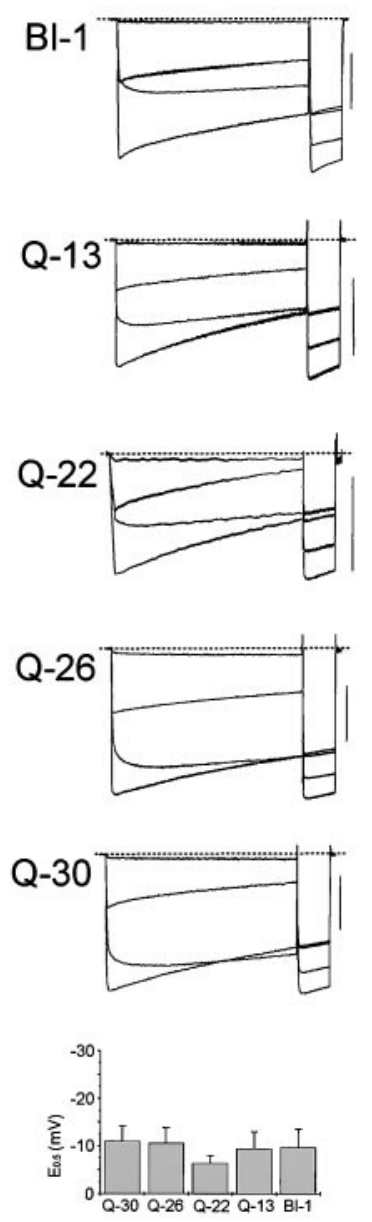

$\alpha_{1 \mathrm{~A}}-\mathrm{Qn}+\alpha_{2}-\delta+\beta_{2}$
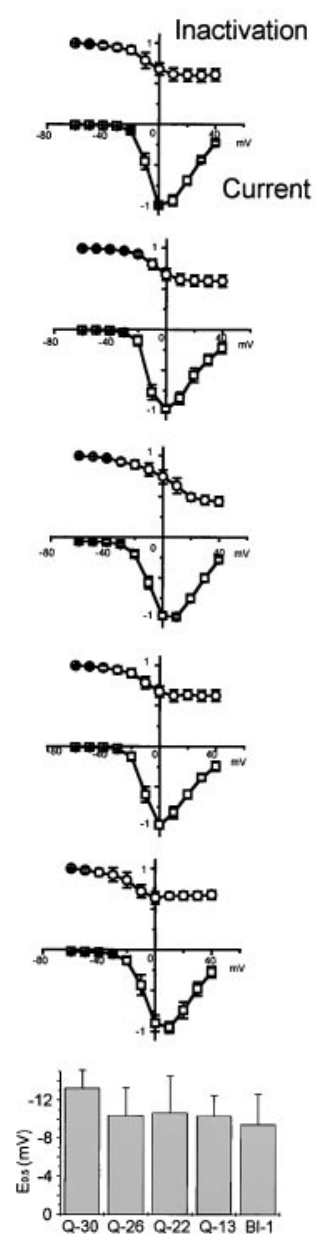

Figure 3. $A, I-V$ and inactivation properties of polyQ mutants co-expressed with $\alpha_{2}-\delta$ and $\beta_{4}$. Left, Current traces recorded during a two-pulse protocol. The first pulse had a duration of $2.5 \mathrm{sec}$ and amplitudes of $-30,-10,10$, and $30 \mathrm{mV}$, whereas the second pulse had a duration of $400 \mathrm{msec}$ and an amplitude of $+10 \mathrm{mV}$. From top to bottom, current traces recorded from oocytes expressing the BI-1, Q-13, Q-22, Q-26, or Q-30 chimeric $\alpha_{1 \mathrm{~A}}$ subunit together with the $\alpha_{2}-\delta$ and the $\beta_{4}$ subunit. Calibration, $0.5 \mu \mathrm{A}$. Right, Inactivation and normalized $I-V$ curves averaged from recordings performed on 5-12 oocytes of each combination. Bottom, Midpoint of activation $\left(\mathrm{Va}_{0.5}\right.$, left $)$, and midpoint of inactivation $\left(\mathrm{Vi}_{0.5}\right.$, right $)$ calculated from recordings of each Ca ${ }^{2+}$ channel subunit combination. Note that although polyQ expansion did not modify the steady-state inactivation curves, $I-V$ curves were significantly $(p<0.05)$ shifted toward negative potential for the Q-30 mutation. $B, I-V$ and inactivation properties of polyQ mutants co-expressed with $\alpha_{2}-\delta$ and $\beta_{2}$. Recording conditions and analysis were identical to those in $A$, except that the $\beta_{2}$ subunit was expressed in place of the $\beta_{4}$ subunit. Calibration, $0.5 \mu \mathrm{A}$. Note that in this case, no significant change was noticed in the $I-V$ curves.

domains I and II ( $\left.\mathrm{L}_{\mathrm{I}-\mathrm{II}}\right)$, adjacent to the primary $\beta$ subunit interaction domain (De et al., 1997), and a second in the $\mathrm{C}$ terminus N-terminal to the putative polyQ tract (Qin et al., 1997; Furukawa et al., 1998; Simen and Miller, 1998). Because the $\beta_{4}$ subunit also interacts with the $\alpha_{1 \mathrm{~A}}$ subunit C terminus (Walker et al., 1998), we sought to determine whether G-protein regulation of the long exon $47 \alpha_{1 \mathrm{~A}}$ isoform differed from that of the BI- 1 isoform or whether this regulation was perturbed by the presence of an expanded polyglutamine tract.

To investigate $\mathrm{G}$-protein regulation, we used the activity of the $\mathrm{G}$ protein-coupled $\mu$-opioid receptor. We co-injected in vitrotranscribed cRNAs for the $\mu$-opioid receptor and G $\alpha$ o cDNA together with combinations of $\mathrm{Ca}^{2+}$ channel subunits, including normal or mutated $\alpha_{1 \mathrm{~A}}$ subunit and $\alpha_{2}-\delta$ and $\beta_{4}$ subunits. We tested the effect of perfusion of the $\mu$-opiod agonist DAMGO on $\mathrm{Ba}^{2+}$ currents evoked by consecutive pulses $(50 \mathrm{msec}$ at $0 \mathrm{mV})$ every 3 sec. Figure $7 A$ shows typical current traces and time course of inhibition and recovery for a single subunit combination. To quantitate the extent of regulation, we calculated the degree of inhibition at the steady state of DAMGO (Fig. $7 B$ ). We found that addition of the sequence encoded by the wild-type extended 47 (Q-13 clone) conferred a greater degree of G-protein regulation than seen with the BI-1 isoform without the exon 47 extension.
Similar findings were obtained with Q22 chimera. In contrast, the $\mathrm{G}$ protein regulation conferred by the long exon 47 sequence appeared to be abolished in the Q26 and Q30 chimeric $\alpha_{1 \mathrm{~A}}$ subunits. Thus, the wild-type long exon $47 \alpha_{1 \mathrm{~A}}$ subunit is sensitive to G-protein regulation, which is in turn impaired by the expanded polyQ tract in SCA6.

\section{DISCUSSION}

The discovery of the genetic basis of SCA6 was accompanied by the recognition of a novel splice form of the $\alpha_{1 \mathrm{~A}}$ subunit expressing a previously unrecognized reading frame of exon 47 of the gene CACNA1A (Zhuchenko et al., 1997). In the human gene this exon encodes the polymorphic polyglutamine tract that is expanded in SCA6 (Zhuchenko et al., 1997). Because the distribution and properties of $\alpha_{1 \mathrm{~A}}$ subunits expressing this novel sequence were unknown, and because of its importance in the disease, we studied the pattern of $\alpha_{1 \mathrm{~A}}$ polypeptide isoforms and tissue distribution of the exon 47-encoded sequence. Our immunoblot and immunohistochemical analysis indicates that exon 47 is frequently translated, is present on multiple $\alpha 1 \mathrm{~A}$ isoforms, and is expressed heavily in Purkinje cells and in lesser amounts throughout the CNS. Therefore, although restricted expression of the extended sequence of exon 47 cannot completely account for the selectivity of the Pur- 
A

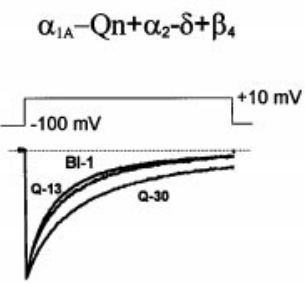

$\alpha_{1 \mathrm{~A}}-\mathrm{Qn}+\alpha_{2}-\delta+\beta_{2}$

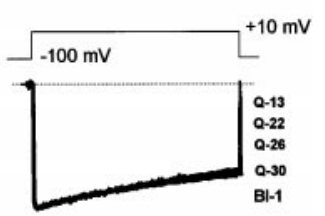

B
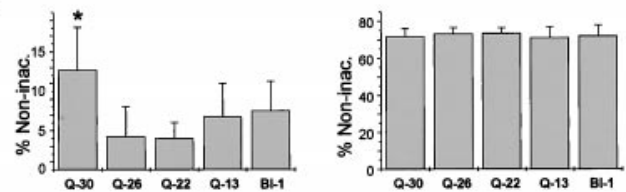

Figure 4. PolyQ expansions in $\alpha_{1 \mathrm{~A}}$ subunit cause delayed inactivation. $A$, Superimposed current traces recorded from oocytes expressing BI-1, Q-13, or Q-30 $\alpha_{1 \mathrm{~A}}$ subunit and $\alpha_{2}-\delta$ and $\beta_{4}$ (left) or $\beta_{2}$ (right). The voltage-clamp protocol ( $2.5 \mathrm{sec}$ duration) is shown on top. All traces are scaled at the same amplitude to facilitate kinetic comparison. $B$, The speed of inactivation of each combination was quantitated by dividing the current at the end of the pulse by the peak current (percent noninactivating). Note that when co-expressed with the $\beta_{4}$ subunit, the Q-30 mutant inactivated significantly slower than the other mutants. This effect is not seen when co-expressed with the $\beta_{2}$ subunit.

kinje cell death in SCA6, its abundance in these cells may play an important role.

Expansion of the polyQ tract in the $\mathrm{C}$ terminus of the $\alpha_{1 \mathrm{~A}}$ subunit has three discrete effects when $\mathrm{P} / \mathrm{Q}$ channels are expressed in oocytes: (1) the voltage dependence of channel activation evoked by $10 \mathrm{mV}$ steps is shifted in the hyperpolarizing direction; (2) the rate of inactivation during a $10 \mathrm{mV}$ pulse is slowed; and (3) regulation by $\mathrm{G}$-proteins conferred by the $\mathrm{C}$ terminus is abolished. The first two of these effects exhibit a $\beta$ subunit dependence and are not seen when the chimeric subunits are co-expressed with $\beta_{2}$ or $\beta_{3}$ subunits. These studies support the model of SCA6 as a channelopathy.

The findings in this study are distinct from those of other groups. Matsuyama et al. (1999) have found that expression of recombinant $\alpha_{1 \text { A }}$ subunits encoding a Q-30 or Q-40 (exaggerated) polyglutamine tract caused reduced current density and an $8 \mathrm{mV}$ shift in the voltage dependence of inactivation in the hyperpolarizing direction. The net effect of this change would be to reduce the number of channels available for activation. Recent studies using an $\alpha_{1 \mathrm{~A}}$ subunit with a tagged epitope in a similar system showed an increased current density and increased level of expression (Piedras-Renteria et al., 1999). In both studies there was a small shift in the voltage dependence of activation in the hyperpolarizing direction that did not reach statistical significance for either spontaneous (Q-27 or Q-30) or exaggerated (not found in humans, Q-40 or Q-72) alleles.

At least three explanations may account for these different findings. (1) In the present study $\alpha_{1 \mathrm{~A}}$ subunit alleles were co-expressed with $\beta_{2}, \beta_{3}$, or $\beta_{4}$ subunits, whereas the $\beta_{1 \mathrm{a}}$ (the muscle-specific) and $\beta_{1 \mathrm{~b}}$ isoforms were used in the other studies (Matsuyama et al., 1999; Piedras-Renteria et al., 1999). The clear dependence of the SCA6 effect on $\beta$ subunit subtype in our study further indicates the importance of an auxiliary subunit subtype in shaping $\mathrm{P} / \mathrm{Q}$ channel activity and may account for the different findings. (2) In this study, the use of the Xenopus oocyte expression system rather than mammalian cells may have led to distinct or more robust responses. It will be important to determine whether the recordings in oocytes represent an exaggeration of the effect in vivo or whether the recordings in mammalian cells with distinct $\beta$ subunit subtypes exhibit the same effect. (3) In the present study the $3^{\prime}$ portion of the correctly spliced human 46-47 cDNA (with the polyQ allele substituted) was added to the cDNA encoding the rabbit BI-1 isoform
A $\alpha_{1 \mathrm{~A}}-\mathrm{Qn}+\alpha_{2}-\delta+\beta_{4} \quad \alpha_{1 \mathrm{~A}}-\mathrm{Qn}+\alpha_{2}-\delta+\beta_{2}$
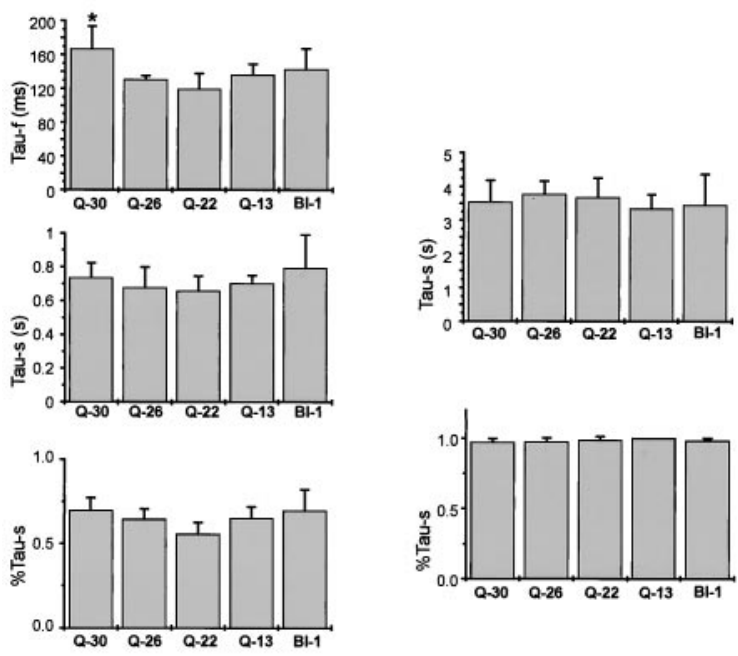

B

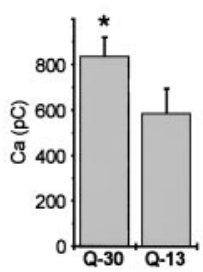

Figure 5. Inactivation kinetics of polyQ mutants co-expressed with $\alpha_{2}-\delta$ and $\beta_{4}$ or $\beta_{2}$. A, Kinetic analysis of the inactivation phase of the different polyQ mutants co-expressed with $\alpha_{2}-\delta$ and $\beta_{4}$ or $\beta_{2}$. In each case the inactivation phase could be described by two exponential components, $\tau$-f and $\tau$-s. However, although $\alpha_{1 \mathrm{~A}}$ mutant $\mathrm{Ca}^{2+}$ channels co-expressed with $\beta_{4}$ had a slow component ( $\tau$-s) accounting for $\sim 70 \%$ (no statistical differences among the different mutants) of the inactivation phase, this component represented $99 \%$ of the inactivation when the $\beta_{2}$ subunit was expressed. The only effect of the polyQ mutation (Q-30) was to increase the fast phase of inactivation $\left(\tau\right.$-f), leaving the slow phase $\left(\tau\right.$-s) unaffected (whether $\beta_{2}$ or $\beta_{4}$ was expressed). $B$. Calculating the integral of the current traces recorded from oocytes expressing either the Q-13 or Q-30 $\alpha_{1 \mathrm{~A}}$ subunit plus $\alpha_{2}-\delta$ and $\beta_{4}$ shows that, for a current of a given amplitude, the pathological expansion increased significantly $(p<0.05)$ the quantity of $\mathrm{Ca}^{2+}$ entering into the cell.

of the $\alpha_{1 \mathrm{~A}}$ subunit rather than inserting the polyglutamine tract directly into the rabbit in frame $3^{\prime}$ untranslated region (UTR) (Matsuyama et al., 1999). Thus, the chimeric $\alpha_{1 \mathrm{~A}}$ subunits in the present study possess 253 amino acids encoded by human exons 46 and 47. Although the rabbit BI-1 3' UTR encodes a sequence $90 \%$ identical to the human extended $\alpha_{1 \mathrm{~A}}$ isoform, subtle differences may be important (Zhuchenko et al., 1997).

The $\mathrm{C}$ terminus of the $\alpha_{1 \mathrm{~A}}$ subunit in $\mathrm{P} / \mathrm{Q}$ channels participates in $\beta$ subunit interactions and $\mathrm{Ca}^{2+}$-calmodulin-mediated regulation and contains an interaction domain for G-protein regulation. (Qin et al., 1997; Furukawa et al., 1998; Simen and Miller, 1998). The sequence encoded by the entire exon 47 nearly doubles the length of the $\mathrm{C}$ terminus of the $\alpha_{1 \mathrm{~A}}$ subunit by the addition of 246 amino acids (Zhuchenko et al., 1997). Although this exon encodes the polymorphic polyglutamine tract and SCA6-associated expanded polyQ alleles, the wild-type Q-13 and mildly expanded $\mathrm{Q}-22$ alleles appear to have no effect on $\mathrm{P} / \mathrm{Q}$ channel activation or inactivation. On the other hand, chimeric Q-13 and Q-22 $\alpha_{1 \mathrm{~A}}$ subunits are more susceptible to inhibition by G-protein than is BI-1, as demonstrated by the inhibitory effect of the opioid agonist DAMGO when channels were co-expressed with the $\mu$-opioid receptor. This may account for some differences in disease severity and disease phenotype associated with different CAG repeat sizes 

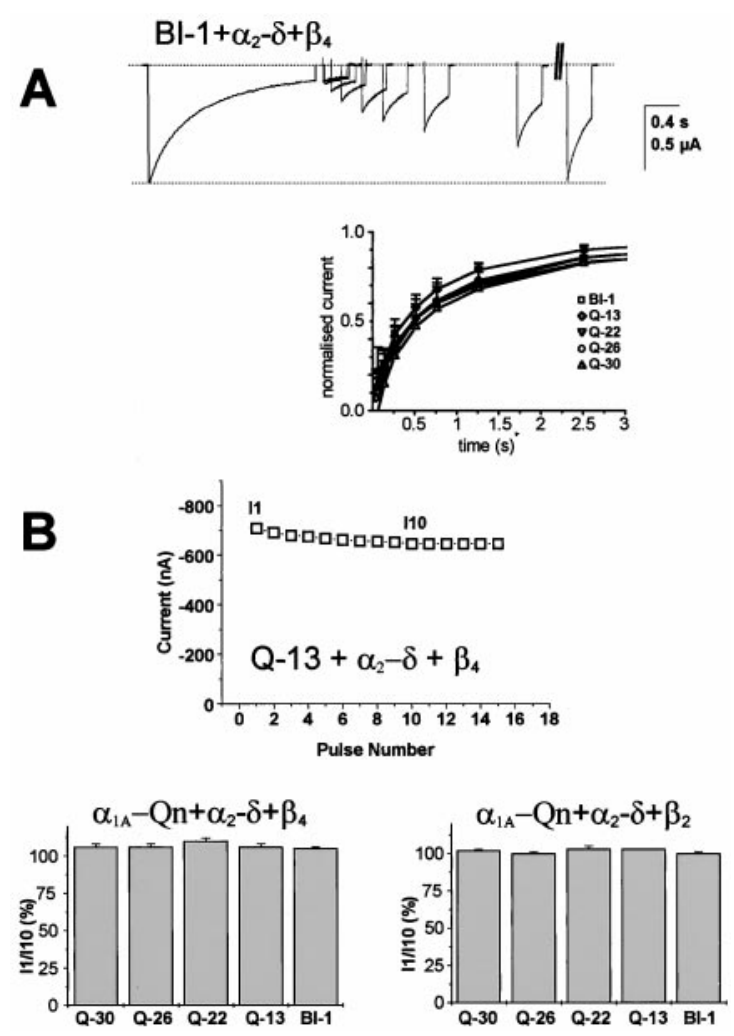

Figure 6. PolyQ expansions do not affect recovery from inactivation or response to repetitive stimulation. $A$, Recovery from inactivation was recorded during test pulses applied at various times after the conditioning pulse ( $2.5 \mathrm{sec}$ duration). Peak currents were normalized and plotted against time. Typical current traces recorded from oocytes expressing BI-1 plus $\alpha_{2}-\delta$ and $\beta_{4}$ are shown. Recovery time courses are not significantly affected by Q-13, Q-22, Q-26, and Q-30. B, PolyQ expansion did not affect current decay during stimulation at $1 \mathrm{~Hz}$. After a period of rest $(>20 \mathrm{sec})$, a train of depolarization $(1 \mathrm{~Hz},+10 \mathrm{mV}$ ) was applied, and successive Ba currents were recorded. Peak current amplitudes recorded for each pulse were then plotted against pulse number as exemplified at the top for an oocyte expressing Q-13 plus $\alpha_{2}-\delta$ and $\beta_{4}$. Current decay during this train was then quantified by dividing peak current recorded at the 1 st pulse by peak current recorded at the 10th pulse $(I 1 / I 10)$. No statistical differences in $\mathrm{I} 1 / \mathrm{I} 10$ (at $p=0.05$ level) were noted between BI-1 and normal (Q-13) and pathological (Q-22, Q-26, and Q-30) chimeric $\alpha_{1 \mathrm{~A}}$ subunit expressed with $\alpha_{2}-\delta$ and either $\beta_{4}$ or $\beta_{2}$.

(Kaseda et al., 1999). Curiously, the larger expanded alleles, Q-26 and Q-30, appear to interfere with the regulatory role of the C terminus. This provides a second aspect of the molecular phenotype of the mutant $\mathrm{P} / \mathrm{Q}$ channels in SCA6 and may explain the differences found in the activation properties of the different alleles.

The dependence of $\beta$ subunit subtype in determining the phenotype of the SCA6 mutation is a plausible finding. $\beta$ subunits have a prominent effect on gating of VGCC (De and Campbell, 1995; Cens et al., 1999). $\beta$ subunit subtypes diverge greatly in primary structure in their $\mathrm{C}$ termini, and the $\beta_{4}$ subunit has a unique $\mathrm{C}$ terminus interaction with the $\alpha_{1 \mathrm{~A}}$ subunit $\mathrm{C}$ terminus (Walker et al., 1998). The expanded polyglutamine tract in the SCA6associated $\alpha_{1 \mathrm{~A}}$ subunit may alter channel gating by interfering with this $\beta_{4}$-specific interaction with the $\alpha_{1 \mathrm{~A}} \mathrm{C}$ terminus.

Among several allelic mouse neurological mutants affecting CACNA1A, the recessively inherited tg $^{\text {la }}$ (leaner) mouse bears the greatest similarity to SCA6. Homozygous $\mathrm{tg}^{\text {la }}$ mice develop dystonia, severe ataxia, and absence seizures after weaning (Fletcher et al., 1996). They develop Purkinje cell degeneration, but it is confined to parasagittal striped domains overlapping the pattern of zebrin expression in the cerebellar cortex (Fletcher et al., 1996). The $\operatorname{tg}^{\text {la }}$ mutation disrupts the $\mathrm{C}$ terminus of the $\alpha_{1 \mathrm{~A}}$ subunit and presumably interactions with the $\beta_{4}$ subunit, G-protein $\beta \gamma$, and
A
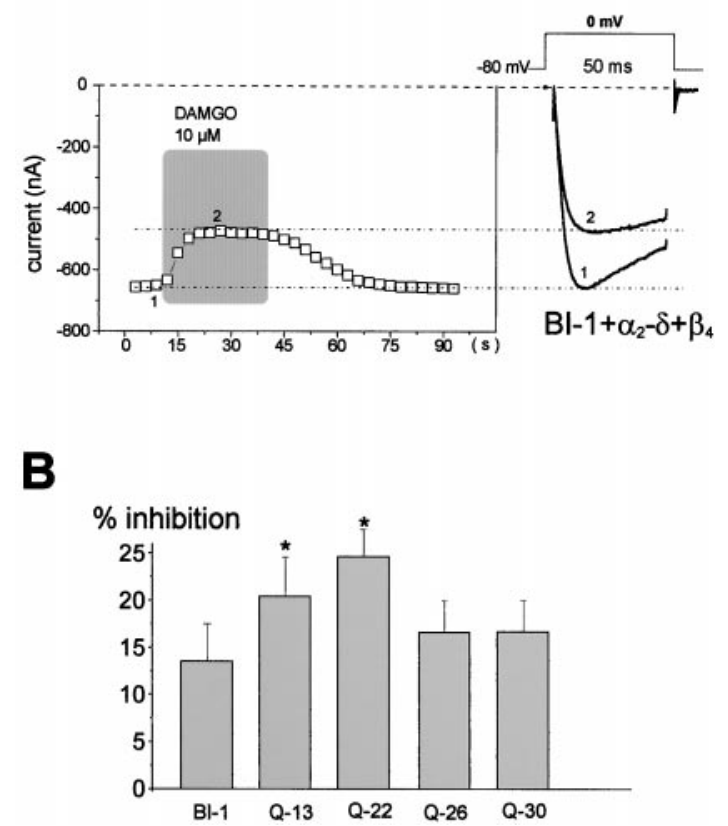

Figure 7. G-protein regulation of mutant $\alpha_{1 \mathrm{~A}} \mathrm{Ca}^{2+}$ channels. $A$, Combinations of $\mathrm{Ca}^{2+}$ channel subunits including normal or mutated $\alpha_{1 \mathrm{~A}}$ subunit and $\alpha_{2}-\delta$ and $\beta_{4}$ subunits were co-injected with the $\mu$-opioid receptor and $\mathrm{G} \alpha \mathrm{O}$ cDNA. Currents were recorded during test pulses of $50 \mathrm{msec}$ to 0 $\mathrm{mV}$ (every $3 \mathrm{sec}$ ), and G-protein-dependent regulation was assessed by perfusing the $\mu$-opioid agonist DAMGO $(10 \mu \mathrm{M})$. Typical current traces and time course of inhibition and recovery are shown. $B, \mathrm{G}$-protein inhibition was quantitated by calculating the degree of inhibition at the steadystate effect of DAMGO. No statistical differences were found between the $\mathrm{BI}-1$ and the mutated subunits presenting various degrees of polyQ expansion (Q-13, Q-22, Q-26, and Q-30).

$\mathrm{Ca}^{2+}$-calmodulin kinase (Furukawa et al., 1998; Walker et al., 1998; Lee et al., 1999). Cultured $t^{\text {la }}$ Purkinje cells have reduced $\mathrm{Ca}^{2+}$ current density, a molecular phenotype that is replicated in recombinant expression studies, as well as an increase in the noninactivating component of calcium currents (Wakamori et al., 1998).

In SCA6, Purkinje cell degeneration is not confined to parasagittal zones (Gomez et al., 1997a; Sasaki et al., 1998; Ishikawa et al., 1999a). Moreover, we found that immunostaining with anti-CT1 did not reflect any compartmentalization of exon 47 expression into parasagittal zones in rat cerebella (data not shown). Thus, although the two types of $\mathrm{Ca}^{2+}$ channel mutations appear to have some opposing effects on $\mathrm{P} / \mathrm{Q}$-type $\mathrm{Ca}^{2+}$ channel activity, differences in the inheritance pattern, age of onset, and tissue selectivity between the two resulting diseases suggest a model in which Purkinje cell development and viability depend on tight control of $\mathrm{Ca}^{2+}$ channel function and the avoidance of either abnormally increased or decreased $\mathrm{Ca}^{2+}$ current. The congenital myasthenic syndromes represent a similar case in which weakness and impaired neuromuscular transmission can arise from either homozygous inactivating mutations or heterozygous "gain-of-function" mutations of the acetylcholine receptor subunits (Engel et al., 1996a,b; Gomez et al., 1996).

The changes in $\mathrm{P} / \mathrm{Q}$ channel properties resulting from the SCA6 mutations will have several effects on the electrophysiological and cellular properties of the Purkinje cells. In isolation, a delay in inactivation of the magnitude measured in this study will result in entry of 1.3 -fold greater $\mathrm{Ca}^{2+}$ per activation. This could significantly increase the amount of $\mathrm{Ca}^{2+}$ entering the Purkinje cell during climbing fiber activity or other influences that activate $1 \mathrm{~Hz}$ complex spike activity (Kitazawa et al., 1998; Lang et al., 1999).

The effect of the shift in activation of $\mathrm{P} / \mathrm{Q}$ channels toward the hyperpolarizing direction could have a more dramatic effect on 
both Purkinje cell firing and intracellular ion content. In the absence of any compensatory response, this change would potentially lead to opening of a greater number of VGCC and entry of more $\mathrm{Ca}^{2+}$. At the physiological level, excessive $\mathrm{Ca}^{2+}$ ions entering through the SCA6-mutant channels might be compensated for by downregulation of gene expression of the $\alpha_{1 \mathrm{~A}}$ subunit. This is apparently not the case, because immunohistochemical staining of $\alpha_{1 \mathrm{~A}}$ subunits in SCA6 cerebellar Purkinje cells shows normal levels (Ishikawa et al., 1999b). If sufficient to exceed the intracellular buffering capacity, $\mathrm{Ca}^{2+}$ overload could result in activation of $\mathrm{Ca}^{2+}$-sensitive enzymes, such as caspases, calpain, and phospholipases, leading to cell death, as has been suggested for other conditions characterized by excitotoxity or $\mathrm{Ca}^{2+}$ overload (Mattson, 1992; Choi, 1994; Dugan and Choi, 1994; Gomez et al., 1997b).

Neurodegeneration in SCA6 is highly selective for Purkinje cells (Gomez et al., 1997a; Sasaki et al., 1998; Ishikawa et al., 1999a). On the basis of their prominent involvement in other multisystem degeneration (Durr et al., 1995; Durr et al., 1996; Koeppen, 1998), Purkinje cells appear to be a vulnerable cell type. However, expression of the SCA6-associated exon 47 is more prominent in the Purkinje cells than in many other regions. Furthermore, expression of the $\beta_{4}$ subunit is more abundant in Purkinje cells than in other areas (Burgess et al., 1999). There are conflicting reports on the relative level of expression of $\beta_{3}$ (Tanaka et al., 1995; Ludwig et al., 1997; Volsen et al., 1997; Burgess et al., 1999). The strikingly selective degeneration of Purkinje cells may relate in part to the combined effect of a high level of Purkinje cell expression of the pathogenic splice form and its co-localization with the $\beta_{4}$ subunit. Regional co-localization studies at the subcellular level combined with co-immunoprecipitation studies may clarify this issue.

Another study has demonstrated the presence of cytoplasmic aggregates in Purkinje cells in SCA6 (Ishikawa et al., 1999b). These aggregates may arise because of self-association properties of the polyglutamine tract. Although it is difficult to envision how cytoplasmic aggregates could contribute to altered channel function, the formation of these associations while inserted in the membrane of the Purkinje cell soma or dendrite could have a prominent effect on channel gating.

These studies show that the SCA6 polyglutamine expansion causes a change in the function of an endogenous ion channel molecule, suggesting that SCA6 differs qualitatively from the other characterized forms of SCA. Although abnormal protein folding may yet underlie this perturbed channel function in SCA6, recognition that SCA6 is a channelopathy may lead to development of rational drug therapies. Further advances using co-localization studies and neuronal expression studies in vitro and in vivo may reveal more details of the pathogenesis of SCA6.

\section{REFERENCES}

Anonymous (1993) A novel gene containing a trinucleotide repeat that is expanded and unstable on Huntington's disease chromosomes. The Huntington's Disease Collaborative Research Group. Cell 72:971-983.

Barchi RL (1998) Ion channel mutations affecting muscle and brain. Curr Opin Neurol 11:461-468.

Becher MW, Kotzuk JA, Sharp AH, Davies SW, Bates GP, Price DL, Ross CA (1998) Intranuclear neuronal inclusions in Huntington's disease and dentatorubral and pallidoluysian atrophy: correlation between the density of inclusions and IT15 CAG triplet repeat length. Neurobiol Dis 4:387-397.

Boonyapisit K, Kaminski HJ, Ruff RL (1999) Disorders of neuromuscular junction ion channels. Am J Med 106:97-113.

Burgess DL, Biddlecome GH, McDonough SI, Diaz ME, Zilinski CA, Bean BP, Campbell KP, Noebels JL (1999) Beta subunit reshuffling modifies $\mathrm{N}$ - and $\mathrm{P} / \mathrm{Q}$-type $\mathrm{Ca}^{2+}$ channel subunit compositions in lethargic mouse brain. Mol Cell Neurosci 13:293-311.

Cens T, Restituito S, Charnet P (1999) Regulation of Ca-sensitive inactivation of a 1-type $\mathrm{Ca}^{2+}$ channel by specific domains of beta subunits. FEBS Lett 450:17-22.

Choi DW (1994) Calcium and excitotoxic neuronal injury. Ann NY Acad Sci 747:162-171.

Cooper EC, Jan LY (1999) Ion channel genes and human neurological disease: recent progress, prospects, and challenges. Proc Natl Acad Sci USA 96:4759-4766.

Cummings CJ, Mancini MA, Antalffy B, DeFranco DB, Orr HT, Zoghbi HY (1998) Chaperone suppression of aggregation and altered subcellu- lar proteasome localization imply protein misfolding in SCA1. Nat Genet 19:148-154.

David G, Abbas N, Stevanin G, Durr A, Yvert G, Cancel G, Weber C, Imbert G, Saudou F, Antoniou E, Drabkin H, Gemmill R, Giunti P, Benomar A, Wood N, Ruberg M, Agid Y, Mandel JL, Brice A (1997) Cloning of the sca7 gene reveals a highly unstable cag repeat expansion. Nat Genet 17:65-70.

De Waard M, Campbell KP (1995) Subunit regulation of the neuronal alpha $1 \mathrm{~A} \mathrm{Ca}^{2+}$ channel expressed in Xenopus oocytes. J Physiol (Lond) 485:619-634

De Waard M, Liu H, Walker D, Scott VE, Gurnett CA, Campbell KP (1997) Direct binding of G-protein betagamma complex to voltagedependent calcium channels. Nature 385:446-450.

Denier C, Ducros A, Vahedi K, Joutel A, Thierry P, Ritz A, Castelnovo G, Deonna T, Gerard P, Devoize JL, Gayou A, Perrouty B, Soisson T, Autret A, Warter JM, Vighetto A, Van BP, Alamowitch S, Roullet E, Tournier LE (1999) High prevalence of CACNA1A truncations and broader clinical spectrum in episodic ataxia type 2. Neurology 52:1816-1821.

Dove LS, Abbott LC, Griffith WH (1998) Whole-cell and single-channel analysis of p-type calcium currents in cerebellar Purkinje cells of leaner mutant mice. J Neurosci 18:7687-7699.

Dugan LL, Choi DW (1994) Excitotoxicity, free radicals, and cell membrane changes. Ann Neurol 35:S17-S21.

Durr A, Smadja D, Cancel G, Lezin A, Stevanin G, Mikol J, Bellance R, Buisson GG, Chneiweiss H, Dellanave J, et al (1995) Autosomal dominant cerebellar ataxia type I in Martinique (French West Indies). Clinical and neuropathological analysis of 53 patients from three unrelated SCA2 families. Brain 118:1573-1581.

Durr A, Stevanin G, Cancel G, Duyckaerts C, Abbas N, Didierjean O, Chneiweiss H, Benomar A, Lyon CO, Julien J, Serdaru M, Penet C, Agid Y, Brice A (1996) Spinocerebellar ataxia 3 and Machado-Joseph disease: clinical, molecular, and neuropathological features. Ann Neurol 39:490-499

Engel AG, Ohno K, Bouzat C, Sine SM, Griggs RC (1996a) End plate acetylcholine receptor deficiency due to nonsense mutations in the epsilon subunit. Ann Neurol 40:810-817.

Engel AG, Ohno K, Milone M, Wang HL, Nakano S, Bouzat C, Pruitt JN, Hutchinson DO, Brengman JM, Bren N, Sieb JP, Sine SM (1996b) New mutations in acetylcholine receptor subunit genes reveal heterogeneity in the slow-channel congenital myasthenic syndrome. Hum Mol Genet 5:1217-1227.

Fletcher CF, Lutz CM, O’Sullivan TN, Shaughnessy JJ, Hawkes R, Frankel WN, Copeland NG, Jenkins NA (1996) Absence epilepsy in tottering mutant mice is associated with calcium channel defects. Cell 87:607-617.

Furukawa T, Nukada T, Mori Y, Wakamori M, Fujita Y, Ishida H, Fukuda K, Kato S, Yoshii M (1998) Differential interactions of the C terminus and the cytoplasmic I-II loop of neuronal $\mathrm{Ca}^{2+}$ channels with $\mathrm{G}$-protein alpha and beta gamma subunits. I. Molecular determination. J Biol Chem 273:17585-17594.

Gomez CM, Maselli R, Lasalde J, Tamamizu S, Cornblath DR, Lehar M, McNamee M, Kuncl RW (1996) A $\beta$ subunit mutation in the acetylcholine receptor channel gate causes severe slow-channel syndrome. Ann Neurol 39:717-723.

Gomez CM, Thompson R, Gammack J, Pearlman S, Dobyns W, Truwit C, Zee D, Clark HB, Anderson JH (1997a) SCA6: horizontal gaze-evoked and vertical nystagmus, Purkinje cell degeneration and variable age of onset. Ann Neurol 42:933-950.

Gomez CM, Maselli R, Gundeck JE, Chao M, Day JW, Tamamizu S, Lasalde JA, McNamee M, Wollmann RL (1997b) Slow-channel transgenic mice: a model of postsynaptic organellar degeneration at the neuromuscular junction. J Neurosci 17:4170-4179.

Ishikawa K, Watanabe M, Yoshizawa K, Fujita T, Iwamoto H, Yoshizawa T, Harada K, Nakamagoe K, Komatsuzaki Y, Satoh A, Doi M, Ogata T, Kanazawa I, Shoji S, Mizusawa H (1999a) Clinical, neuropathological, and molecular study in two families with spinocerebellar ataxia type 6 (SCA6). J Neurol Neurosurg Psychiatry 67:86-89.

Ishikawa K, Fujigasaki H, Saegusa H, Ohwada K, Fujita T, Iwamoto H, Komatsuzaki Y, Toru S, Toriyama H, Watanabe M, Ohkoshi N, Shoji S, Kanazawa I, Tanabe T, Mizusawa H (1999b) Abundant expression and cytoplasmic aggregations of alpha $1 \mathrm{~A}$ voltage-dependent calcium channel protein associated with neurodegeneration in spinocerebellar ataxia type 6. Hum Mol Genet 8:1185-1193.

Jen J (1999) Calcium channelopathies in the central nervous system. Curr Opin Neurobiol 9:274-280.

Kaseda Y, Kawakami H, Matsuyama Z, Kumagai R, Toji M, Komure O, Nishimura M, Izumi Y, Udaka F, Kameyama M, Nishio T, Sunohara N, Kuroda Y, Nakamura S (1999) Spinocerebellar ataxia type 6 in relation to CAG repeat length. Acta Neurol Scand 99:209-212.

Kawaguchi Y, Okamoto T, Taniwaki M, Aizawa M, Inoue M, Katayama S, Kawakami H, Nakamura S, Nishimura M, Akiguchi I, Kimura J, Narumiya S, Kakizuka A (1994) CAG expansions in a novel gene for Machado-Joseph disease at chromosome 14q32.1. Nat Genet 8:221-228.

Kitazawa S, Kimura T, Yin PB (1998) Cerebellar complex spikes encode both destinations and errors in arm movements. Nature 392:494-497.

Koeppen AH (1998) The hereditary ataxias. J Neuropathol Exp Neurol 57:531-543. 
Lang EJ, Sugihara I, Welsh JP, Llinas R (1999) Patterns of spontaneous Purkinje cell complex spike activity in the awake rat. J Neurosci 19:2728-2739.

Lee A, Wong ST, Gallagher D, Li B, Storm DR, Scheuer T, Catterall WA (1999) $\mathrm{Ca}^{2+} /$ calmodulin binds to and modulates P/Q-type calcium channels. Nature 399:155-159.

Li SH, Li XJ (1998) Aggregation of N-terminal huntingtin is dependent on the length of its glutamine repeats. Hum Mol Genet 7:777-782.

Lin Z, Haus S, Edgerton J, Lipscombe D (1997) Identification of functionally distinct isoforms of the N-type $\mathrm{Ca}^{2+}$ channel in rat sympathetic ganglia and brain. Neuron 18:153-166.

Ludwig A, Flockerzi V, Hofmann F (1997) Regional expression and cellular localization of the alpha(1) and beta subunit of high voltageactivated calcium channels in rat brain. J Neurosci 17:1339-1349.

Matsuyama Z, Minoru W, Mori Y, Kawakami H, Nakamura S, Imoto K (1999) Direct alteration of the P/Q-type $\mathrm{Ca}^{2+}$ channel property by polyglutamine expansion in spinocerebellar ataxia $6 . \mathrm{J}$ Neurosci 19(RC-14):1-5.

Mattson MP (1992) Calcium as sculptor and destroyer of neural circuitry. Exp Gerontol 27:29-49.

Mori Y, Friedrich T, Kim MS, Mikami A, Nakai J, Ruth P, Bosse E, Hofmann F, Flockerzi V, Furuichi T, et al (1991) Primary structure and functional expression from complementary DNA of a brain calcium channel. Nature 350:398-402.

Mori Y, Wakamori M, Matsuyama Z, Fletcher C, Copeland NG, Jenkins NA, Oda S, Imoto K (1999) A defect in voltage sensor of P/Q-type $\mathrm{Ca}^{2+}$ channel is associated with the ataxic mouse mutation, rolling Nagoya (tgrol). Soc Neurosci Abstr 25:721.

Ophoff RA, Terwindt GM, Vergouwe MN, Van Eijk R, Oefner PJ, Hoffman SM, Lamerdin JE, Mohrenweiser HW, Bulman DE, Ferrari M, Haan J, Lindhout D, van Omman GJ, Hofker MH, Ferrari MD, Frants RR (1996) Familial hemiplegic migraine and episodic ataxia type-2 are caused by mutations in the $\mathrm{Ca}^{2+}$ channel gene CACNL1A4. Cell $87: 543-552$.

Orr HT, Chung M-y, Banfi S, Kwiatkowski Jr TJ, Servadio A, Beaudet AL, McCall AE, Duvick LA, Ranum LPW, Zoghbi HY (1993) Expansion of an unstable trinucleotide CAG repeat in spinocerebellar ataxia type 1 . Nat Genet 4:211-226.

Paulson HL, Perez MK, Trottier Y, Trojanowski JQ, Subramony SH, Das SS, Vig P, Mandel JL, Fischbeck KH, Pittman RN (1997) Intranuclear inclusions of expanded polyglutamine protein in spinocerebellar ataxia type 3. Neuron 19:333-344.

Piedras-Renteria ES, Watase K, Zoghbi HY, Lee CC, Tsien RW (1999) Alteration of expressed $\alpha 1 \mathrm{~A} \mathrm{Ca}^{2+}$ channel currents arising from expanded trinucleotide repeats in spinocerebellar ataxia type 6. Soc Neurosci Abstr 25:1056.

Qin N, Platano D, Olcese R, Stefani E, Birnbaumer L (1997) Direct interaction of gbetagamma with a C-terminal gbetagamma-binding domain of the $\mathrm{Ca}^{2+}$ channel alpha1 subunit is responsible for channel inhibition by $G$ protein-coupled receptors. Proc Natl Acad Sci USA 94:8866-8871.

Sakurai T, Hell JW, Woppmann A, Miljanich GP, Catterall WA (1995) Immunochemical identification and differential phosphorylation of alternatively spliced forms of the alpha 1 A subunit of brain calcium channels. J Biol Chem 270:21234-21242.
Sakurai T, Westenbroek RE, Rettig J, Hell J, Catterall WA (1996) Biochemical properties and subcellular distribution of the BI and rbA isoforms of alpha $1 \mathrm{~A}$ subunits of brain calcium channels. J Cell Biol 134:511-528.

Sasaki H, Kojima H, Yabe I, Tashiro K, Hamada T, Sawa H, Hiraga H, Nagashima K (1998) Neuropathological and molecular studies of spinocerebellar ataxia type 6 (sca6). Acta Neuropathol (Berl) 95:199-204.

Simen AA, Miller RJ (1998) Structural features determining differential receptor regulation of neuronal Ca channels. J Neurosci 18:3689-3698.

Skinner PJ, Koshy BT, Cummings CJ, Klement IA, Helin K, Servadio A, Zoghbi HY, Orr HT (1997) Ataxin-1 with an expanded glutamine tract alters nuclear matrix-associated structures. Nature 389:971-974.

Takahashi H, Ikeuchi T, Honma Y, Hayashi S, Tsuji S (1998) Autosomal dominant cerebellar ataxia (SCA6): clinical, genetic and neuropathological study in a family. Acta Neuropathol (Berl) 95:333-337.

Tanaka O, Sakagami H, Kondo H (1995) Localization of mRNAs of voltage-dependent $\mathrm{Ca}(2+)$-channels: four subtypes of alpha 1 - and betasubunits in developing and mature rat brain. Brain Res Mol Brain Res 30:1-16.

Tournier LE (1999) CACNA1A mutations: hemiplegic migraine, episodic ataxia type 2, and the others. Neurology 53:3-4.

Volsen SG, Day NC, McCormack AL, Smith W, Craig PJ, Beattie RE, Smith D, Ince PG, Shaw PJ, Ellis SB, Mayne N, Burnett JP, Gillespie A, Harpold MM (1997) The expression of voltage-dependent calcium channel beta subunits in human cerebellum. Neuroscience 80:161-174.

Wakamori M, Yamazaki K, Matsunodaira H, Teramoto T, Tanaka I, Niidome T, Sawada K, Nishizawa Y, Sekiguchi N, Mori E, Mori Y, Imoto K (1998) Single tottering mutations responsible for the neuropathic phenotype of the P-type calcium channel. J Biol Chem 273:34857-34867.

Wakamori M, Yamazaki K, Teramoto T, Niidome T, Matsuyama Z, Oda S, Mori Y, Imoto K (1999) Electrophysiological comparison of the P-type calcium channel recorded from Purkinje cells of three types of ataxic mice. Soc Neurosci Abstr 25:721.

Walker D, Bichet D, Campbell KP, De WM (1998) A beta 4 isoformspecific interaction site in the carboxyl-terminal region of the voltagedependent $\mathrm{Ca}^{2+}$ channel alpha 1A subunit. J Biol Chem 273:2361-2367.

Westenbroek RE, Sakurai T, Elliott EM, Hell JW, Starr TV, Snutch TP, Catterall WA (1995) Immunochemical identification and subcellular distribution of the alpha $1 \mathrm{~A}$ subunits of brain calcium channels. J Neurosci 15:6403-6418.

Yabe I, Sasaki H, Matsuura T, Takada A, Wakisaka A, Suzuki Y, Fukazawa T, Hamada T, Oda T, Ohnishi A, Tashiro K (1998) Sca6 mutation analysis in a large cohort of the japanese patients with late-onset pure cerebellar ataxia. J Neurol Sci 156:89-95.

Yue Q, Jen JC, Nelson SF, Baloh RW (1997) Progressive ataxia due to a missense mutation in a calcium-channel gene. Am J Hum Genet 61:1078-1087.

Zhuchenko O, Bailey J, Bonnen P, Ashizawa T, Stockton DW, Amos C, Dobyns WB, Subramony SH, Zoghbi HY, Lee CC (1997) Autosomal dominant cerebellar ataxia (SCA6) associated with small polyglutamine expansions in the alpha 1A-voltage-dependent calcium channel. Nat Genet 15:62-69.

Zwingman TA, Neumann PE, Noebels JL, Herrup K (1999) Rocker, a new allele of tottering. Soc Neurosci Abstr 25:722. 